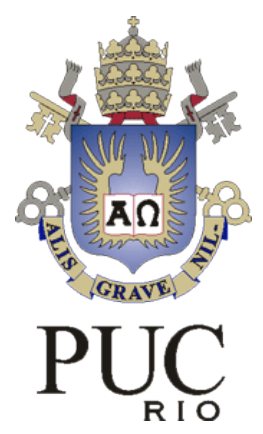

\begin{abstract}
PONTIFÍCIA UNIVERSIDADE CATÓLICA DO RIO DE JANEIRO DEPARTAMENTO DE ENGENHARIA QUÍMICA E MATERIAIS CURSO DE ENGENHARIA DE MATERIAIS E NANOTECNOLOGIA
\end{abstract}

NIKOLAS BRANCO PADILHA

ESPECTROSCOPIA APLICADA A FILMES FINOS DE ÓXIDOS CONDUTORES TRANSPARENTES DESTINADOS À FABRICAÇÃO DE CÉLULAS SOLARES

Rio de Janeiro 


\author{
PONTIFÍCIA UNIVERSIDADE CATÓLICA DO RIO DE JANEIRO \\ CURSO DE ENGENHARIA DE MATERIAIS E NANOTECNOLOGIA
}

\author{
NIKOLAS BRANCO PADILHA
}

\title{
ESPECTROSCOPIA APLICADA A FILMES FINOS DE ÓXIDOS CONDUTORES TRANSPARENTES DESTINADOS À FABRICAÇÃO DE CÉLULAS SOLARES
}

Monografia apresentada no Curso de Graduação em Engenharia de Materiais e Nanotecnologia da Pontifícia Universidade Católica do Rio de Janeiro (PUC-Rio), como parte dos requisitos para obtenção do grau na cadeira Projeto de Graduação em Engenharia de Materiais e Nanotecnologia ENG1145.

Orientador: Prof. Roberto R. de Avillez - PUC-Rio

Co-orientadora: Prof. Leila R. O. Cruz - IME

Rio de Janeiro 
c2015

PONTIFÍCIA UNIVERSIDADE CATÓLICA DO RIO DE JANEIRO

Rua Marquês de São Vicente, 225, Gávea

Rio de Janeiro - RJ CEP: 22451-900

Este exemplar é de propriedade da Pontifícia Universidade Católica do Rio de Janeiro, que poderá incluí-lo em base de dados, armazenar em computador, microfilmar ou adotar qualquer forma de arquivamento.

É permitida a menção, reprodução parcial ou integral e a transmissão entre bibliotecas deste trabalho, sem modificação de seu texto, em qualquer meio que esteja ou venha a ser fixado, para pesquisa acadêmica, comentários e citações, desde que sem finalidade comercial e que seja feita a referência bibliográfica completa.

Os conceitos expressos neste trabalho são de responsabilidade do(s) autor(es) e do(s) orientador(es).

Padilha, Nikolas B.

Espectroscopia aplicada a filmes finos de óxidos condutores transparentes destinados à fabricação de células solares / Nikolas Branco Padilha. - Rio de Janeiro: Pontifícia Universidade Católica Do Rio De Janeiro, 2015.

58 p. : il., graf., tab..

Monografia (Projeto de Graduação em Engenharia de Materiais e Nanotecnologia) - Pontifícia Universidade Católica Do Rio De Janeiro, 2015. 


\section{Resumo}

A necessidade energética após a revolução industrial e a descoberta do efeito fotovoltaico incentivaram o desenvolvimento das células solares. Visando maximizar a relação custo/benefício, pesquisadores buscam obter a maior eficiência possível das células, otimizando todos os seus componentes. O laboratório de filmes finos do Instituto Militar de Engenharia visa contribuir para os avanços tecnológicos nessa área. Neste trabalho, foram comparados espectros de transmitância de amostras de filmes finos de TCO de seis materiais diferentes $\left(\mathrm{SnO}_{2}, \ln _{2} \mathrm{O}_{3}, \mathrm{ZnO}\right.$, $\mathrm{ZnO}: \mathrm{Al}, \mathrm{Zn}_{2} \mathrm{SnO}_{4}$ e $\mathrm{Cd}_{2} \mathrm{SnO}_{4}$ ) utilizados como contatos frontais de células solares. Primeiramente foi discutido 0 método de caracterização chamado de espectrofotometria e quais informações sobre os filmes eram obtidas em cada região medida do espectro eletromagnético. Calculou-se a banda proibida dos materiais, o quanto os filmes transmitem no visível e como a presença de portadores afeta a absorção no infravermelho. De mão de todos os resultados, foi observado que os filmes finos de $\mathrm{ZnO}$ :Al eram os melhores para atuarem como contato frontal de células solares, apresentando alta transmitância no visível (acima de 92\%) e baixa resistividade (abaixo de $10^{-3} \Omega . \mathrm{cm}$ ). 


\begin{abstract}
The global energy demand after the industrial revolution and the discovery of the photovoltaic effect encouraged the development of solar cells. To maximize the cost/benefit ratio, researchers seek to obtain the highest cell efficiency by optimizing all its components. The Thin Film Laboratory at Military Institute of Engineering aims to contribute to the technological advancements in this area. Transmittance spectra of TCO thin films of six different materials $\left(\mathrm{SnO}_{2}, \mathrm{In}_{2} \mathrm{O}_{3}, \mathrm{ZnO}, \mathrm{ZnO}: \mathrm{Al}, \mathrm{Zn}_{2} \mathrm{SnO}_{4}\right.$ e $\mathrm{Cd}_{2} \mathrm{SnO}_{4}$ ) were compared in this project. First, the characterization method called spectrophotometry was discussed; then we tried to find out which type of information about the films could be obtained within each region of the electromagnetic spectrum. The band-gap of the films were obtained and the transmittance in the visible spectrum and the effects of the presence of carriers on the absorption in the infrared region were investigated. It was then observed that thin films of $\mathrm{ZnO}: \mathrm{Al}$ were the best solar cells' front contacts, showing high transmittance in the visible region (above 92\%) and low resistivity (below $10^{-3} \Omega . \mathrm{cm}$ ).
\end{abstract}




\section{Sumário}

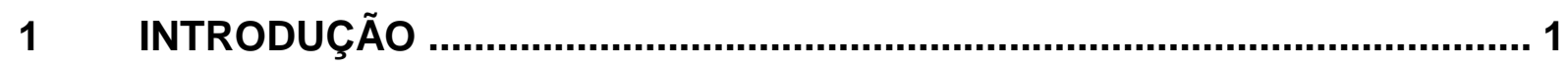

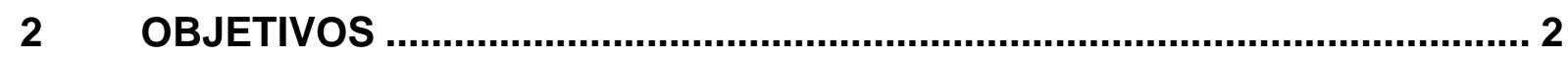

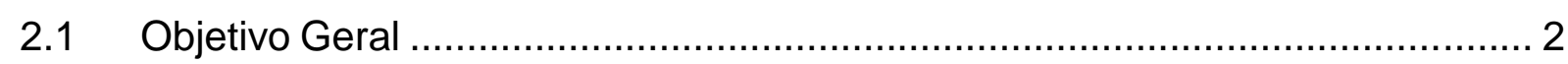

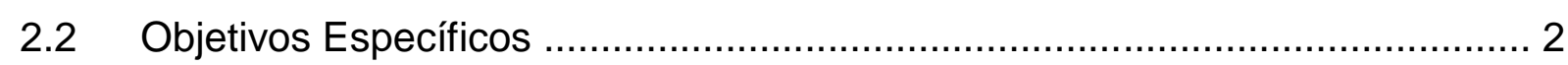

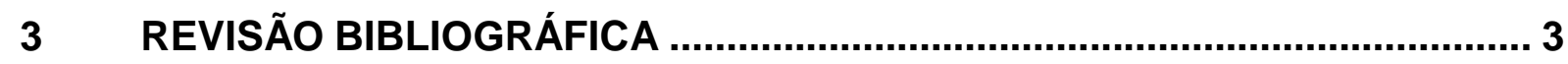

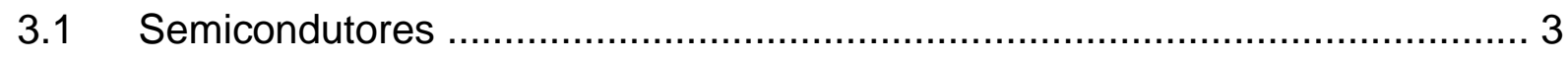

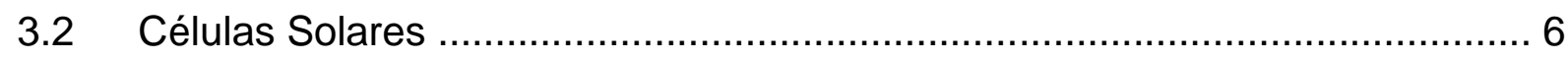

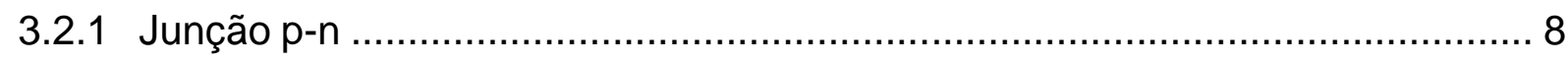

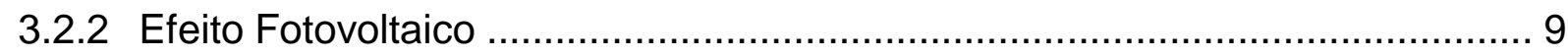

3.3 Óxidos Condutores Transparentes ………………................................. 10

3.4 Materiais utilizados como TCO ……………...................................... 11

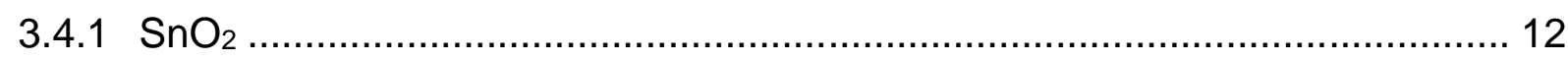

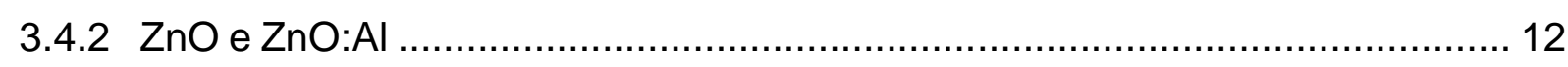

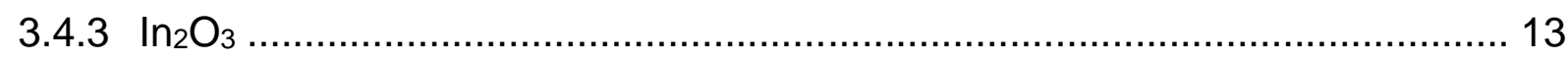

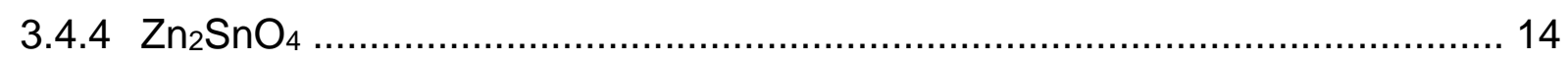

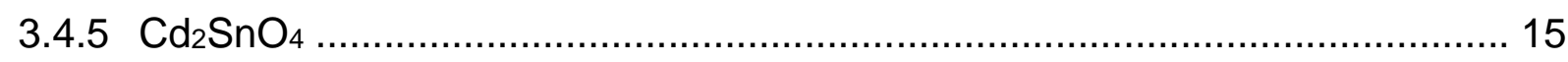

3.5 Métodos de fabricação de filmes finos TCO …................................................ 15

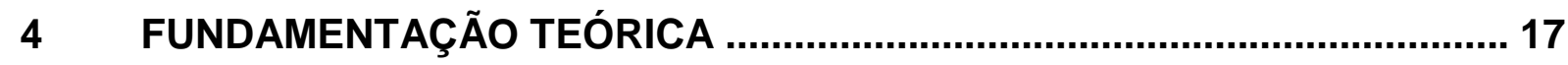

4.1 O Espectrofotômetro e a radiação eletromagnética ........................................ 17

4.2 Análise dos espectros de Transmitância .................................................... 19

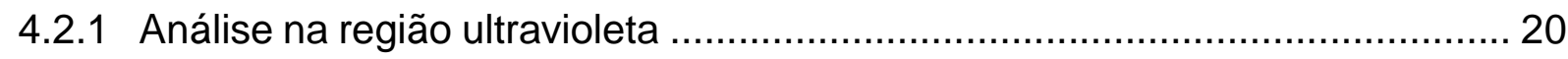

4.2.2 Análise na região visível ................................................................... 22 
4.2.3 Análise na região infravermelha

23

$5 \quad$ MATERIAIS E MÉTODOS ........................................................................ 25

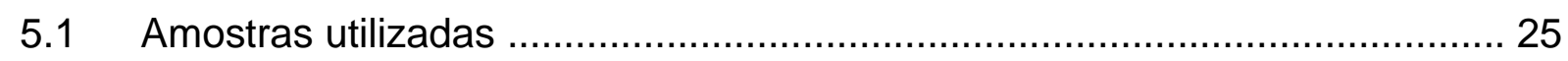

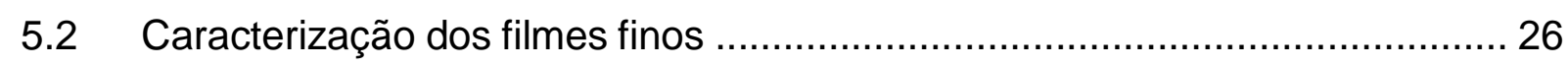

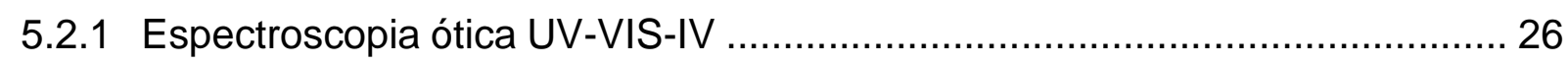

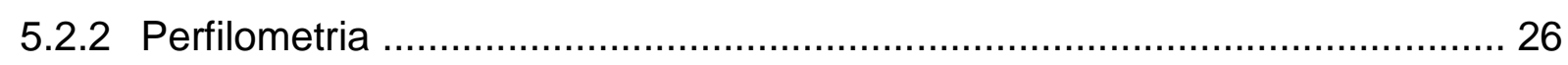

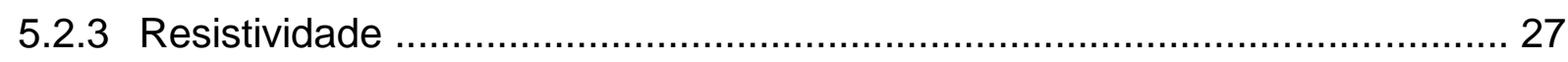

$6 \quad$ RESULTADOS E DISCUSSÃO .............................................................. 28

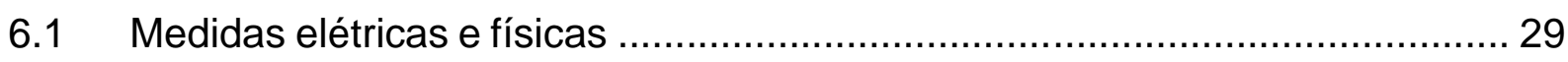

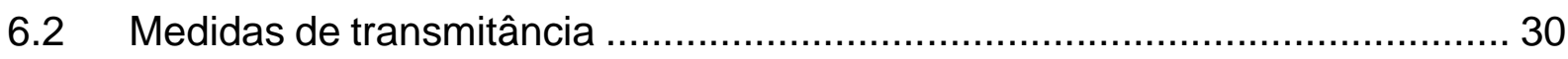

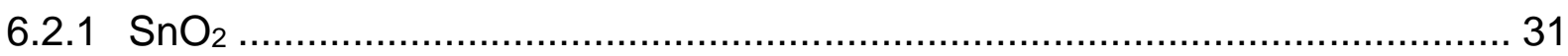

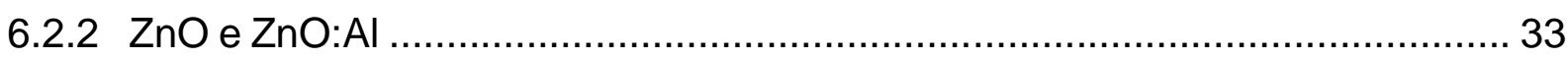

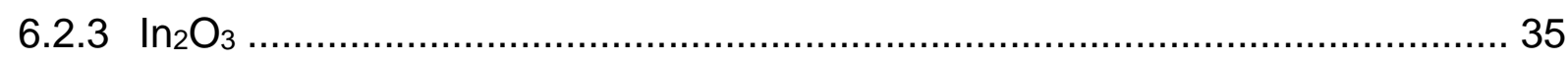

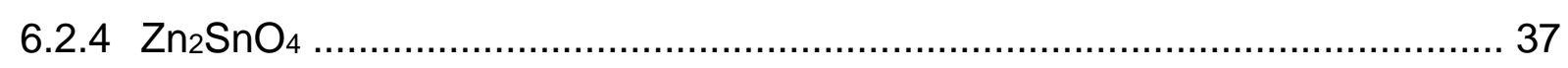

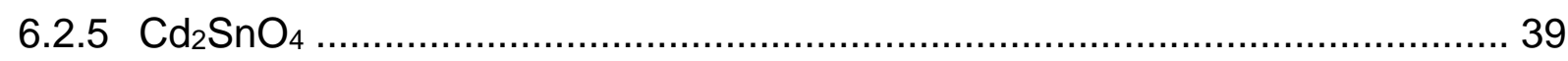

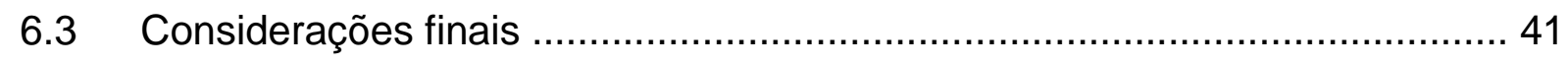

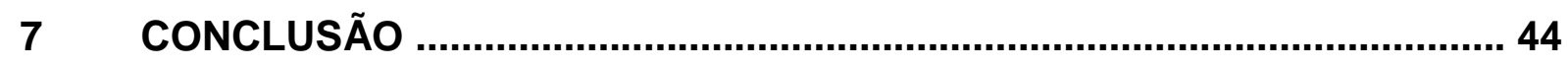

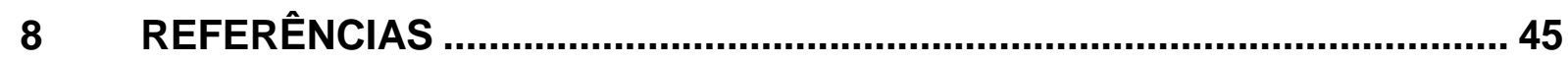




\section{Lista de Tabelas}

Tabela 5.1.1 - Amostras analisadas e seus dados de deposição .25

Tabela 6.1.1 - Amostras analisadas e algumas medidas 29

Tabela 6.2.1 - Valores de Eg dos filmes de $\mathrm{SnO}_{2}$ 32

Tabela 6.2.2 - Valores de \%T no visível dos filmes de $\mathrm{SnO}_{2}$ .32

Tabela 6.2.3 - Valores de Eg dos filmes de ZnO e ZnO:Al 34

Tabela 6.2.4 - Valores de \%T no visível dos filmes de $\mathrm{ZnO}$ e $\mathrm{ZnO}: \mathrm{Al}$ 34

Tabela 6.2.5 - Valores de Eg dos filmes de $\ln _{2} \mathrm{O}_{3}$ 36

Tabela 6.2.6 - Valores de \%T no visível dos filmes de $\ln _{2} \mathrm{O}_{3}$ 37

Tabela 6.2.7 - Valores de Eg dos filmes de $\mathrm{Zn}_{2} \mathrm{SnO}_{4}$ 38

Tabela 6.2.8 - Valores de \%T no visível dos filmes de $\mathrm{Zn}_{2} \mathrm{SnO}_{4}$ 38

Tabela 6.2.9 - Valores de Eg dos filmes de $\mathrm{Cd}_{2} \mathrm{SnO}_{4}$ 40

Tabela 6.2.10 - Valores de \%T no visível dos filmes de $\mathrm{Cd}_{2} \mathrm{SnO}_{4}$ 40

Tabela 6.3.1 - Amostras analisadas e seus dados de medidos ou calculados 41

Tabela 6.3.2 - Resistividade das amostras escolhidas 43 


\section{Lista de Figuras}

Figura 3.1.1 - Gráfico esquemático de níveis energéticos. Acima dois átomos inicialmente separados, no meio os mesmos dois átomos interagindo e abaixo quatro átomos semelhantes formando o início das bandas de energia dos sólidos. Observa-se que apenas os níveis mais energéticos interagem 4

Figura 3.1.2 - As várias possíveis estruturas de banda eletrônica em sólidos a 0 K. (a) A estrutura de banda eletrônica encontrada em metais tais como cobre, na qual existem disponíveis estados eletrônicos acima e adjacentes aos estados preenchidos, na mesma banda. (b) A estrutura de banda eletrônica de metais tais como magnésio, onde existe uma superposição da banda de valência preenchida com uma banda de condução vazia. (c) Estrutura de banda eletrônica característica de isolantes; a banda de valência preenchida está separada da banda de condução vazia por uma relativamente grande brecha $(>4,5 \mathrm{eV})$. (d) A estrutura de banda eletrônica encontrada nos semicondutores, que é a mesma para um isolante exceto que a brecha de banda é relativamente estreita $(<4,5 \mathrm{eV})$

Figura 3.1.3 - Elétrons da banda de valência podem absorver os fótons incididos e serem promovidos para a banda de valência. Na figura, fótons de três energias são mostrados. Fótons com energia maior (azul) que a banda proibida tem a diferença de energia (hv-Eg) dissipada em forma de calor. Fótons pouco energéticos (vermelho) não conseguem promover o elétron, logo não são absorvidos

Figura 3.2.1 - Projeções de preço e eficiência de células solares de primeira (I), segunda (II) e terceira (III) geração (tecnologias baseadas em wafer, filmes finos e filmes finos avançados, respectivamente)

Figura 3.2.2 - Diagrama esquemático de uma célula solar .8

Figura 3.2.3 - Representação das bandas de energia de semicondutores e energia de Fermi. Semicondutores (a) intrínseco, (b) tipo n e (c) tipo p. 9 
Figura 3.2.4 - Efeito fotovoltaico .9

Figura 3.4.1 - Estrutura de bandas do $\mathrm{SnO}_{2}$ 12

Figura 3.4.2 - Estrutuda de banda do ZnO cúbico 13

Figura 3.4.3 - Estrutura de bandas do $\ln _{2} \mathrm{O}_{3}$ 14

Figura 3.5.1 - Desenho esquemático da pulverização catódica 16

Figura 4.1.1 - Funcionamento de um espectrofotômetro 18

Figura 4.2.1 - Exemplo de espectro de transmitância 20

Figura 4.2.2 - Diagrama de transições eletrônicas entre BV e BC para absorções (a) direta e (b) indireta 21

Figura 4.2.3 - Exemplo de espectro para cálculo de espessura e índice de refração 23

Figura 4.2.4- Tipos de absorções em diferentes faixas de $\lambda$ 24

Figura 4.2.5 - Transições óticas e subsequente relaxação de energia dentro da banda de valência 24

Figura 5.2.1 - Espectrofotômetro Varian Cary 5000 .26

Figura 5.2.2 - Geometrias comuns de amostras para o método Van der Pauw 27

Figura 6.2.1 - Transmitâncias medidas do vidro, do conjunto vidro-filme e a transmitância calculada para apenas o filme. Espectros referente à amostra $\mathrm{SnO}_{2} \# 1$ e à um vidro padrão 30

Figura 6.2.2 - Transmitâncias das amostras de $\mathrm{SnO}_{2}$ 31

Figura 6.2.3 - Gráfico $\alpha^{2}\left(\mathrm{~cm}^{-2}\right)$ vs. hv (eV) das amostras de $\mathrm{SnO}_{2}$ .31 
Figura 6.2.4 - Transmitâncias das amostras de $\mathrm{ZnO}$ e ZnO:Al 33

Figura 6.2.5 - Gráfico $\mathrm{a}^{2}\left(\mathrm{~cm}^{-2}\right)$ vs. hv (eV) das amostras de $\mathrm{ZnO}$ e $\mathrm{ZnO}: \mathrm{Al}$ 34

Figura 6.2.6 - Transmitâncias das amostras de $\ln _{2} \mathrm{O}_{3}$ 35

Figura 6.2.7 - Gráfico $a^{2}\left(\mathrm{~cm}^{-2}\right)$ vs. hv $(\mathrm{eV})$ das amostras de $\ln _{2} \mathrm{O}_{3}$ 36

Figura 6.2.8 - Transmitâncias das amostras de $\mathrm{Zn}_{2} \mathrm{SnO}_{4}$ .37

Figura 6.2.9 - Gráfico $\alpha^{2}\left(\mathrm{~cm}^{-2}\right)$ vs. hv (eV) das amostras de $\mathrm{Zn}_{2} \mathrm{SnO}_{4}$. 38

Figura 6.2.10 - Transmitâncias das amostras de $\mathrm{Cd}_{2} \mathrm{SnO}_{4}$ 39

Figura 6.2.11 - Gráfico $\alpha^{2}\left(\mathrm{~cm}^{-2}\right)$ vs. hv $(\mathrm{eV})$ das amostras de $\mathrm{Cd}_{2} \mathrm{SnO}_{4}$ 39

Figura 6.3.1 - Transmitâncias escolhidas .42 


\section{Introdução}

A optoeletrônica é a área de estudo que visa a produção de dispositivos capazes de fornecer, detectar, controlar e absorver a luz. Ela lida com as interações entre a radiação eletromagnética e os campos elétricos dos materiais que são utilizados para a fabricação de muitos dispositivos como lasers, LED, detectores de radiação, câmeras fotográficas, painéis de cristal líquido e células solares.

Os TCO (do inglês Transparent Conductive Oxides, que significa óxidos condutores transparentes) se inserem em inúmeros desses dispositivos proporcionando algo que os metais não conseguem: conduzir eletricidade e ao mesmo tempo serem transparentes à luz de comprimentos de onda na região visível do espectro eletromagnético. Essa propriedade faz com que eles possuam elevado interesse para os pesquisadores de células solares, área de grande importância estratégica no combate à crise energética brasileira e mundial.

Em geral, esses óxidos são utilizados como filmes finos em alguns dispositivos fotovoltaicos para formar o contato frontal e transmitir a radiação solar para a camada seguinte a qual é composta por um semicondutor do tipo $\mathrm{n}$. O principal material utilizado pela indústria atualmente como TCO é o óxido de índio dopado com estanho (ITO), que apresenta baixa resistividade e ótima transmitância, acima de 80\% (Chen et al., 2013). Mesmo sendo muito eficiente em sua função, esse material é caro, já que seu principal componente, o Índio, é um metal raro com preços em torno de 750 dólares por kg em 2014 (European Comission, 2015), em comparação com o preço do estanho, por exemplo, de 14,73 dólares por $\mathrm{kg}$ em novembro de 2015 (London Metal Exchange, 2015).

É natural, portanto, a busca por TCO capazes de substituir o ITO ( $\left.\ln _{2} \mathrm{O}_{3}: \mathrm{Sn}\right)$ e é essa uma das propostas do Laboratório de Filmes Finos do Instituto Militar de Engenharia (LFF/IME). Materiais alternativos como $\mathrm{SnO}_{2}, \mathrm{Cd}_{2} \mathrm{SnO}_{4}, \mathrm{ZnO}, \mathrm{ZnO}: \mathrm{Al}$ e $\mathrm{Zn}_{2} \mathrm{SnO}_{4}$ são depositados na forma de filmes finos sobre substratos de vidro e suas propriedades óticas e elétricas são estudadas a fundo procurando a melhor opção.

Uma ferramenta muito importante no caminho em busca do material ideal é a medida da transmitância do filme. Nela, muitas informações são obtidas, tais como: o quanto o filme de fato deixa a luz passar para as camadas inferiores, qual o tamanho da banda proibida do óxido, o quanto de luz é refletida, dentre outras. 
Neste trabalho, os espectros de transmitância dos filmes finos de TCO foram obtidos no espectrofotômetro "Cary 5000", da Varian Inc., e utilizados como ferramenta de caracterização principal na busca das propriedades optoeletrônicas dos TCO fabricados no LFF/IME para aplicação em células solares.

\section{Objetivos}

\subsection{Objetivo Geral}

Esse projeto busca obter informações sobre banda proibida, resistividade e transparência na região visível do espectro eletromagnético através de medidas elétricas e análise dos espectros de transmissão de filmes finos condutores transparentes para utilização em contatos frontais em células solares. Foram comparadas as propriedades optoelétricas de amostras de TCO dos seguintes materiais: $\mathrm{SnO}_{2}, \mathrm{Cd}_{2} \mathrm{SnO}_{4}, \mathrm{ZnO}, \mathrm{ZnO}: \mathrm{Al}, \mathrm{Zn}_{2} \mathrm{SnO}_{4}$ e $\ln _{2} \mathrm{O}_{3}$.

\subsection{Objetivos Específicos}

2.2.1 Apresentar a técnica de transmitância como método de caracterização através dos cálculos necessários para obter as propriedades do material.

2.2.2 Obter os espectros de transmitância de todos os filmes.

2.2.3 Analisar os gráficos para cada material dividindo-os em regiões do espectro eletromagnético.

2.2.3.1. Região do ultravioleta próximo $(300-400 \mathrm{~nm})$

2.2.3.2. Região do visível $(400-800 \mathrm{~nm})$

2.2.3.3. Região infra vermelha $(800-2000 \mathrm{~nm})$

2.2.4. Definir o que pode ou não ser concluído a partir dos espectros de transmitância de filmes finos de TCO. 


\section{Revisão Bibliográfica}

\subsection{Semicondutores}

Uma das maneiras de classificar materiais sólidos é de acordo com a facilidade com que conduzem uma corrente elétrica. Dentro desta classificação existem 3 grupamentos: condutores, semicondutores e isolantes. Semicondutores podem ter suas propriedades elétricas controladas por uma pequena adição de átomos de impurezas, chamados de dopantes. Com isso, podem ser classificados de duas formas: semicondutores intrínsecos e extrínsecos. Basicamente, semicondutores intrínsecos não apresentam átomos dopantes já os extrínsecos apresentam, o que aumenta a condutividade do material.

Em todos os materiais a condução eletrônica e a magnitude da condutividade elétrica são dependentes do número de elétrons disponíveis para participar do processo de condução, já que nem todos acelerar-se-ão na presença de um campo elétrico. Esse número está relacionado ao arranjo de estados ou níveis de elétrons em relação à energia e deste modo a maneira na qual estes estados são ocupados pelos elétrons.

Para cada átomo individual existem níveis discretos de energia que podem ser ocupados pelos elétrons, definidos pela mecânica quântica, como os "números quânticos". Existem quatro números quânticos, o principal (n), o de momento angular (l), o magnético $\left(m_{\mathrm{l}}\right)$ e o de spin $\left(\mathrm{m}_{\mathrm{s}}\right)$. Eles descrevem os níveis energéticos dos elétrons no átomo e, pelo princípio de exclusão de Pauli, cada elétron sempre possui um conjunto de números quânticos diferente do outro. Em outras palavras, apenas um elétron pode ocupar um estado quântico $\left(n^{*}, l^{*}, m_{l^{*}}, m_{s}^{*}\right)$ (Eisberg, Resnick, 1986).

Um sólido pode ser pensado como consistindo de um grande número de átomos inicialmente separados entre si, que são trazidos ao contato mútuo e ligados para formar um arranjo atômico ordenado encontrado no material cristalino. Quando separados de seus vizinhos, cada átomo é independente de todos os outros e terá níveis de energia atômicos e configurações eletrônicas como se ele estivesse isolado. Entretanto, à medida em que os átomos se aproximam, os elétrons e núcleos de átomos vizinhos começam e interagir. Esta influência é tal que cada estado atômico 
distinto pode se dividir numa série de estados eletrônicos estreitamente espaçados no sólido para formar o que é denominada uma banda de energia eletrônica.

Dentro de cada banda, os estados de energia são discretos, mas a diferença energética entre eles é reduzida ao ponto de ser representados como níveis contínuos. Além disto, lacunas podem existir entre bandas (como indicadas na figura acima) que são denominadas bandas proibidas.

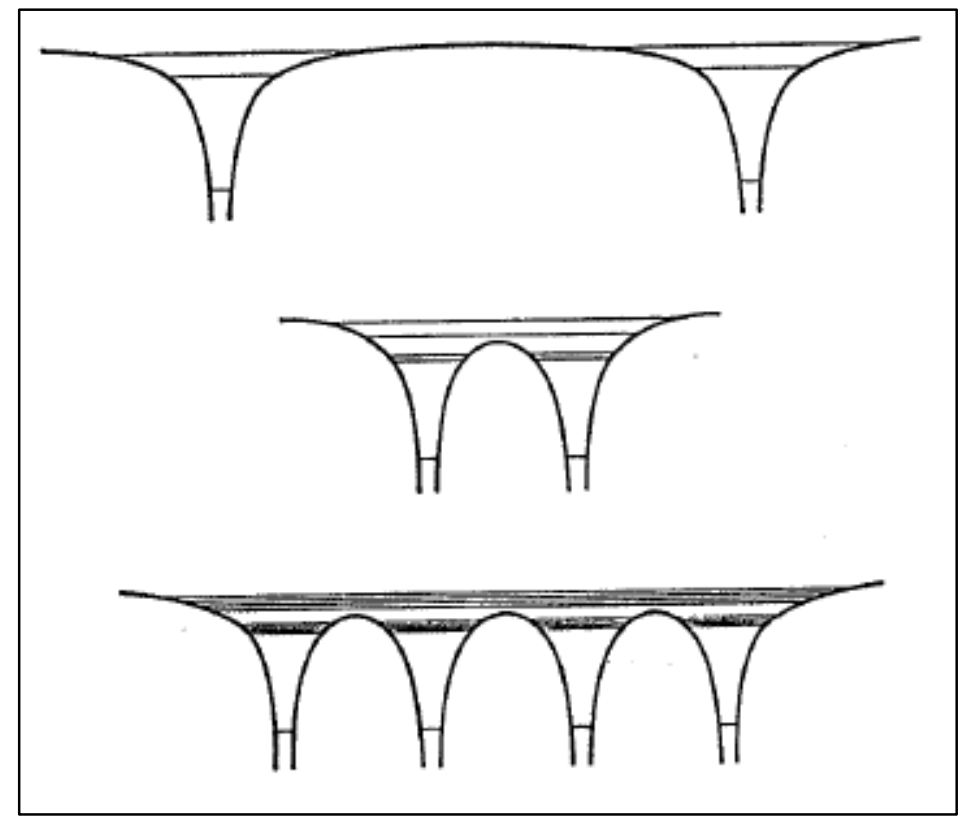

Figura 3.1.1 - Gráfico esquemático de níveis energéticos. Acima dois átomos inicialmente separados, no meio os mesmos dois átomos interagindo e abaixo quatro átomos semelhantes formando o início das bandas de energia dos sólidos. Observa-se que apenas os níveis mais energéticos interagem. (Eisberg, Resnick, 1986.)

Dessa forma, dependendo do material, existirão bandas vazias, bandas parcialmente preenchidas ou bandas completamente preenchidas. As propriedades elétricas de um material sólido são uma consequência de sua estrutura de banda eletrônica e como elas são preenchidas com elétrons. Neste sentido, a banda que contém os elétrons de mais alta energia (ou elétrons de valência) é denominada banda de valência; a banda de condução é a próxima banda de maior energia, que é, sob muitas circunstâncias, virtualmente desocupada por elétrons. 


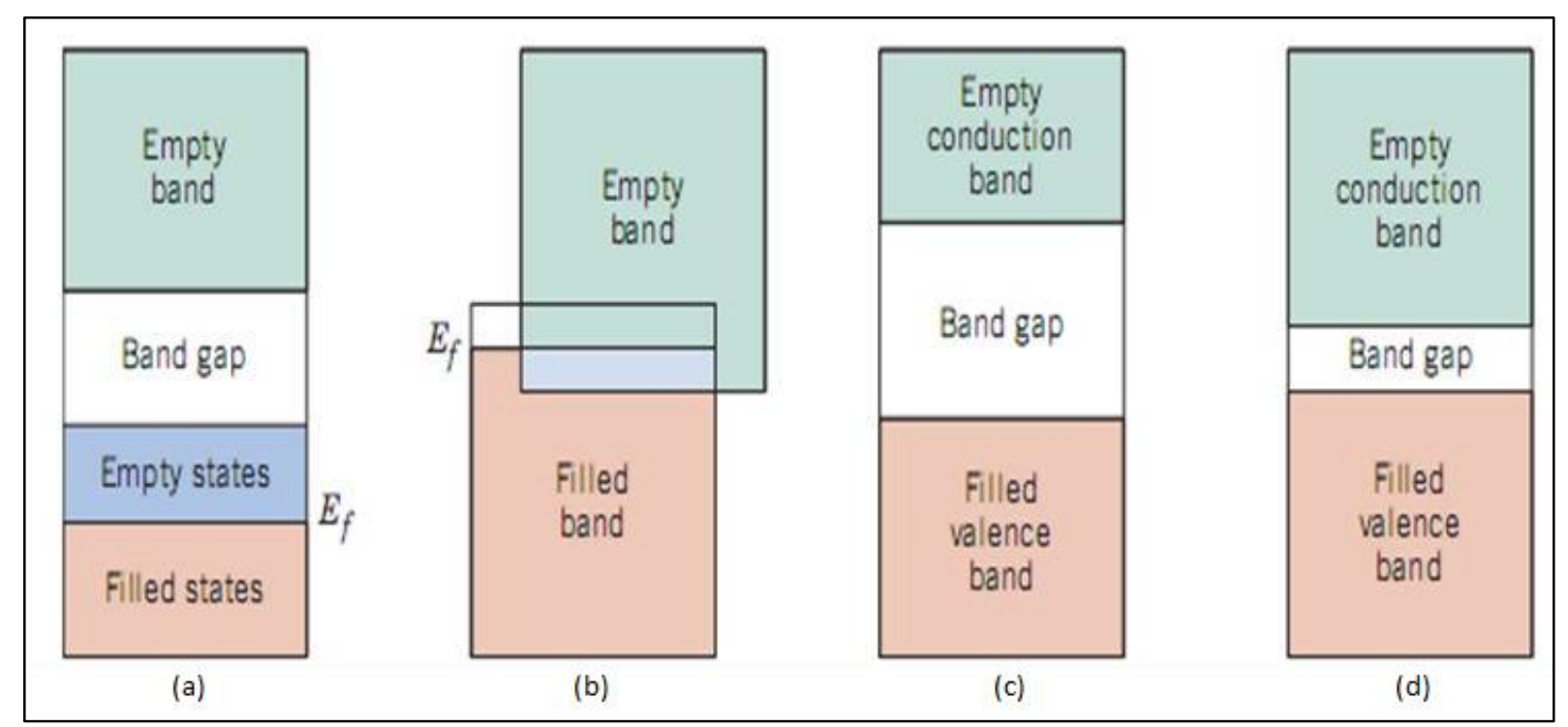

Figura 3.1.2 - As várias possíveis estruturas de banda eletrônica em sólidos a 0 K. (a) A estrutura de banda eletrônica encontrada em metais tais como cobre, na qual existem disponíveis estados eletrônicos acima e adjacentes aos estados preenchidos, na mesma banda. (b) A estrutura de banda eletrônica de metais tais como magnésio, onde existe uma superposição da banda de valência preenchida com uma banda de condução vazia. (c) Estrutura de banda eletrônica característica de isolantes; a banda de valência preenchida está separada da banda de condução vazia por uma relativamente grande brecha $(>4,5 \mathrm{eV})$. (d) A estrutura de banda eletrônica encontrada nos semicondutores, que é a mesma para um isolante exceto que a brecha de banda é relativamente estreita $(<4,5 \mathrm{eV})$. (Adaptado de Callister, 2008.)

Para isolantes e semicondutores, a banda de valência se apresenta muitas vezes totalmente preenchida não possuindo estados vazios necessários para a condução elétrica. Para ficarem livres, portanto, elétrons devem ser promovidos através lacuna de banda de energia e para dentro dos estados vazios na base da banda de condução. Isto é possível apenas mediante o suprimento de energia a um elétron com valor suficiente para que essa barreira seja vencida. Este processo, denominado de excitação, é demonstrado na figura 3.1.3. A energia de excitação pode ser fornecida também por uma fonte não elétrica tal como calor ou luz. 


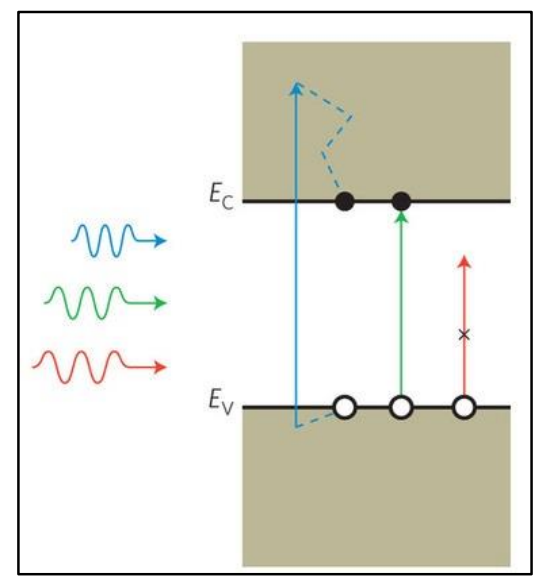

Figura 3.1.3 - Elétrons da banda de valência podem absorver os fótons incididos e serem promovidos para a banda de valência. Na figura, fótons de três energias são mostrados. Fótons com energia maior (azul) que a banda proibida tem a diferença de energia (hv-Eg) dissipada em forma de calor. Fótons pouco energéticos (vermelho) não conseguem promover o elétron, logo não são absorvidos (Chalabi, Brongersma, 2013).

Numa dada temperatura, por exemplo, quanto maior for valor do tamanho da banda proibida $(\mathrm{Eg})$, menor é a probabilidade da promoção de um elétron de valência a um estado de energia dentro da banda de condução, resultando em menos elétrons para condução elétrica. Em outras palavras, quanto maior o Eg, menor será a condutividade elétrica. Assim, a distinção entre semicondutores e isolantes se dá pela largura da banda, que para semicondutores é estreita, enquanto que para materiais isolantes é relativamente larga. Classicamente, o valor de Eg que distinguia um semicondutor de um isolante era em torno de $3 \mathrm{eV}$ (Fraser, 1986), mas já é possível encontrar autores citando materiais com Eg igual a 4,5 eV como sendo semicondutores (Kasap, Capper, 2006).

A elevação da temperatura de um material semicondutor resulta no aumento da energia térmica disponível no material para a excitação eletrônica. Assim, além de mais elétrons serem espontaneamente promovidos para a da banda de condução, o que dá origem a aumentada condutividade, o valor da banda proibida sofre leve diminuição.

\subsection{Células Solares}

Células solares são dispositivos capazes de converter a energia luminosa em corrente elétrica. Baseados no efeito fotovoltaico, são capazes de absorver a radiação eletromagnética com comprimentos de onda dentro ou próximo da faixa da luz visível e estabelecer uma diferença de potencial entre seus terminais. Geralmente 
são fabricados a partir da união de materiais semicondutores em uma configuração conhecida como junção p-n.

Semicondutores do tipo $\mathrm{n}$ ou do tipo $\mathrm{p}$ nada mais são do que semicondutores extrínsecos que possuem átomos dopantes que contribuem com elétrons em excesso ou em falta para a rede do semicondutor, respectivamente. Como consequência, a condutividade elétrica do material é modificada pela, agora, presença de elétrons na banda de condução e de buracos na banda de valência (nome dado aos estados de energia não ocupados na banda de valência) que são também eficazes na movimentação de cargas elétricas.

A homojunção de silício (Si) cristalino é, atualmente, a configuração mais usada no mercado de células solares (Kasap, 2006). Nestas células, o silício possui uma região dopada tipo $\mathrm{n}$ e uma região dopada tipo p. Devido ao alto custo de produção dessas células, pesquisadores têm buscado alternativas através das heterojunções (Kasap, 2006) nas quais um material semicondutor tipo p é depositado sobre um material diferente tipo n ou vice-versa. Este tipo de configuração pode utilizar a tecnologia de filmes finos, onde são produzidas células solares de vários materiais que prometem melhorar muito a relação eficiência vs. custo, como mostra a Figura 3.2.1.

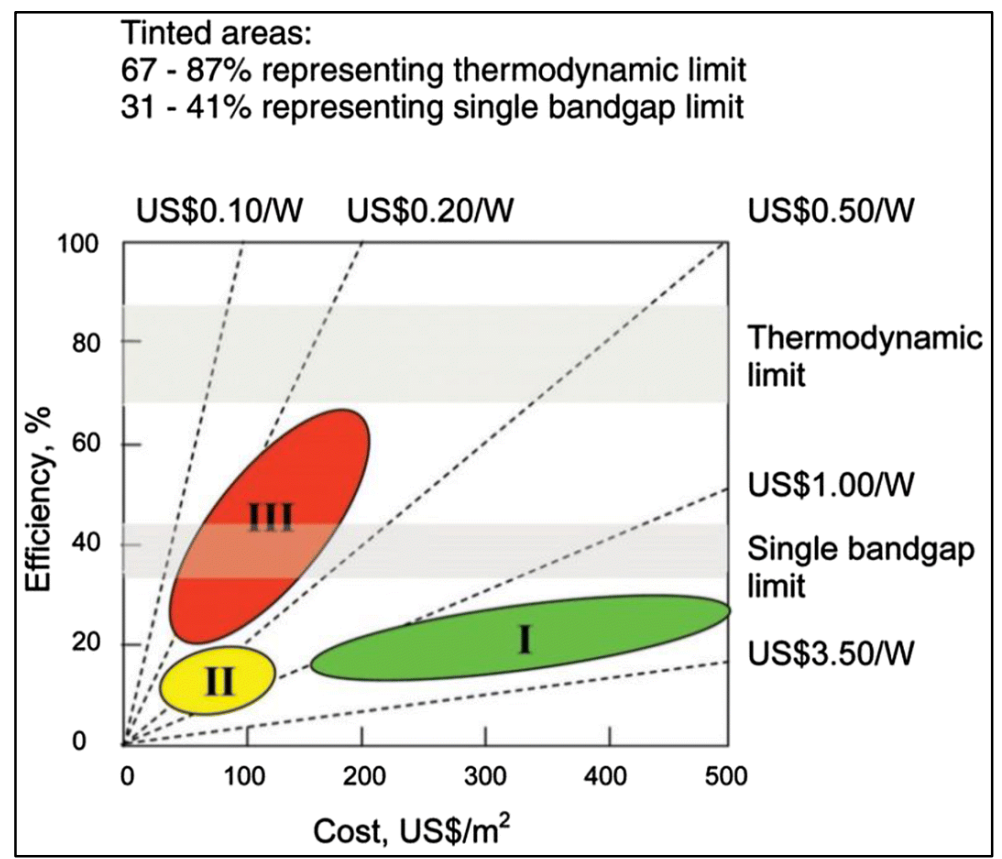

Figura 3.2.1 - Projeções de preço e eficiência de células solares de primeira (I), segunda (II) e terceira (III) geração (tecnologias baseadas em wafer, filmes finos e filmes finos avançados, respectivamente). (Conibeer, 2007) 
Uma das estruturas possíveis de uma célula solar de filme fino é mostrada na figura 3.2.2 e consiste em um substrato a partir de onde a célula será fabricada, um contato frontal de fina camada de material condutor transparente (TCO), uma camada de janela geralmente constituída de um semicondutor tipo $n$, uma camada absorvedora geralmente constituída de semicondutor tipo $p$ e um contato de fundo de material condutor.

É importante observar que o substrato protege a célula da atmosfera e, além disso, como estão localizados na parte frontal da célula, tanto o substrato quanto o contato frontal devem ser o mais transparente possível para permitir a passagem da radiação eletromagnética com comprimento de onda na faixa do visível.

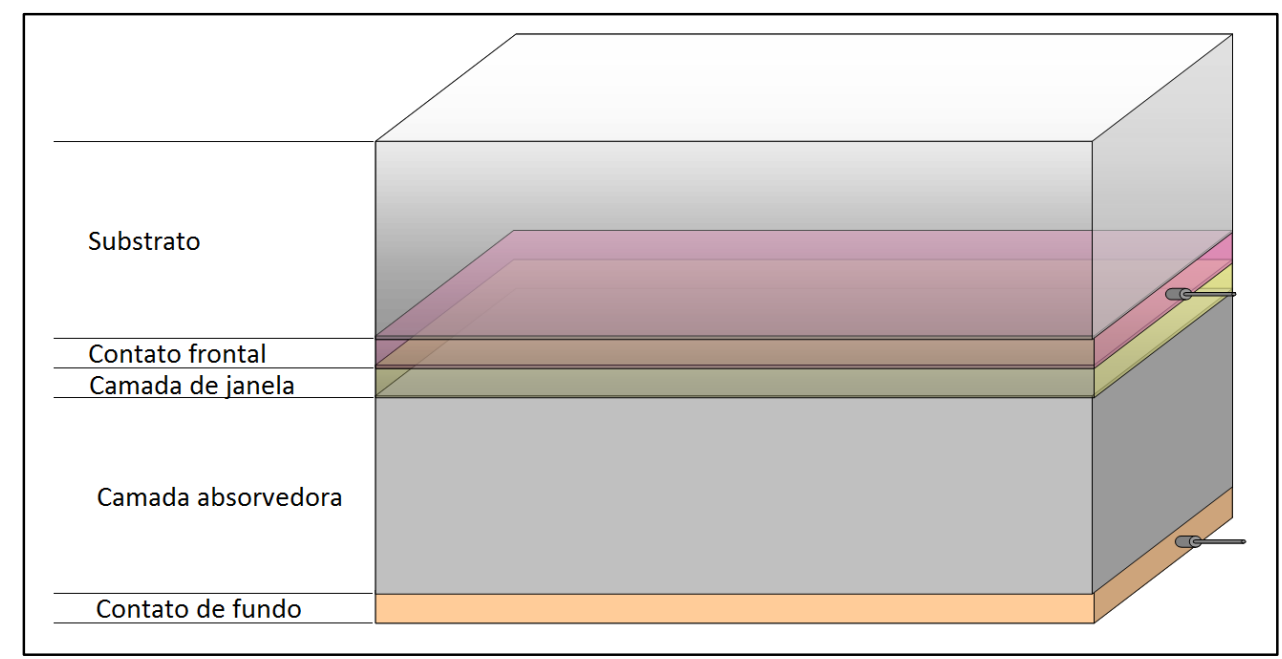

Figura 3.2.2 - Diagrama esquemático de uma célula solar

\subsubsection{JUNÇÃO P-N}

O nível de energia de Fermi é definido como o nível de energia com probabilidade igual a $1 / 2$ de ser ocupado pelos elétrons em sólidos (Kasap, 2006). No caso de um material semicondutor intrínseco, que possui uma quantidade de elétrons na banda de condução igual à quantidade de buracos na banda de valência, este se localiza no meio da banda proibida, conforme mostrado na figura 3.2.3(a). Seguindo essa lógica, vemos na 3.2.3(b) e 3.2.3(c) como a presença de átomos dopantes no semicondutor altera os níveis de energia de Fermi. 


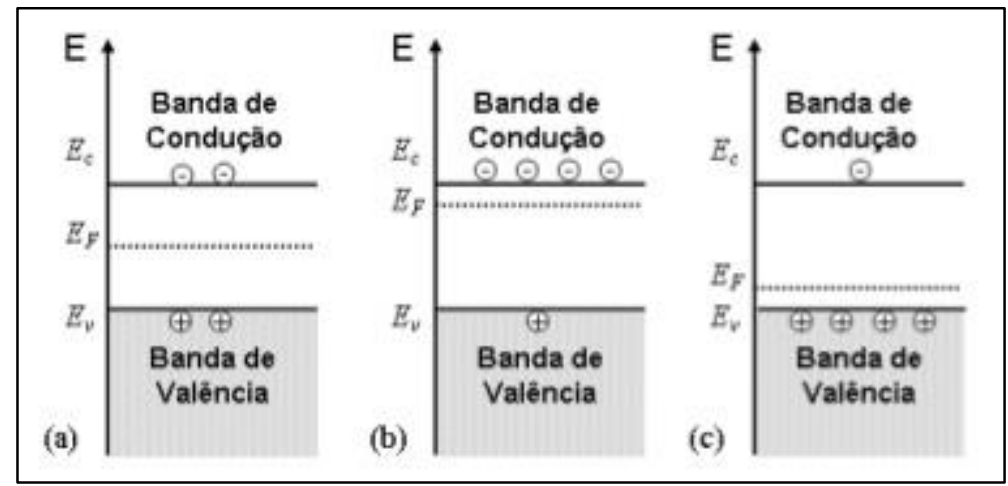

Figura 3.2.3 - Representação das bandas de energia de semicondutores e energia de Fermi.

Semicondutores (a) intrínseco, (b) tipo n e (c) tipo p. (Adaptado de Kasap, 2006)

Ao colocar dois semicondutores em contato para formar uma junção $p-n$, os elétrons do lado $n$ se deslocam para o lado $p$, dando origem a uma corrente de difusão que visa à formação de um nível de Fermi único para todo o material. Quando esse estado é atingido, a diferença de energia entre os dois lados da junção é tal que os elétrons não têm mais energia para passar da camada $n$ para a camada $p$ da junção. Isso faz a corrente de difusão cessar e o sistema entra em um estado de equilíbrio (Kasap, 2006). O estado final desse processo está esquematicamente representado na figura 3.2.4.

\subsubsection{EFEITO FOTOVOLTAICO}

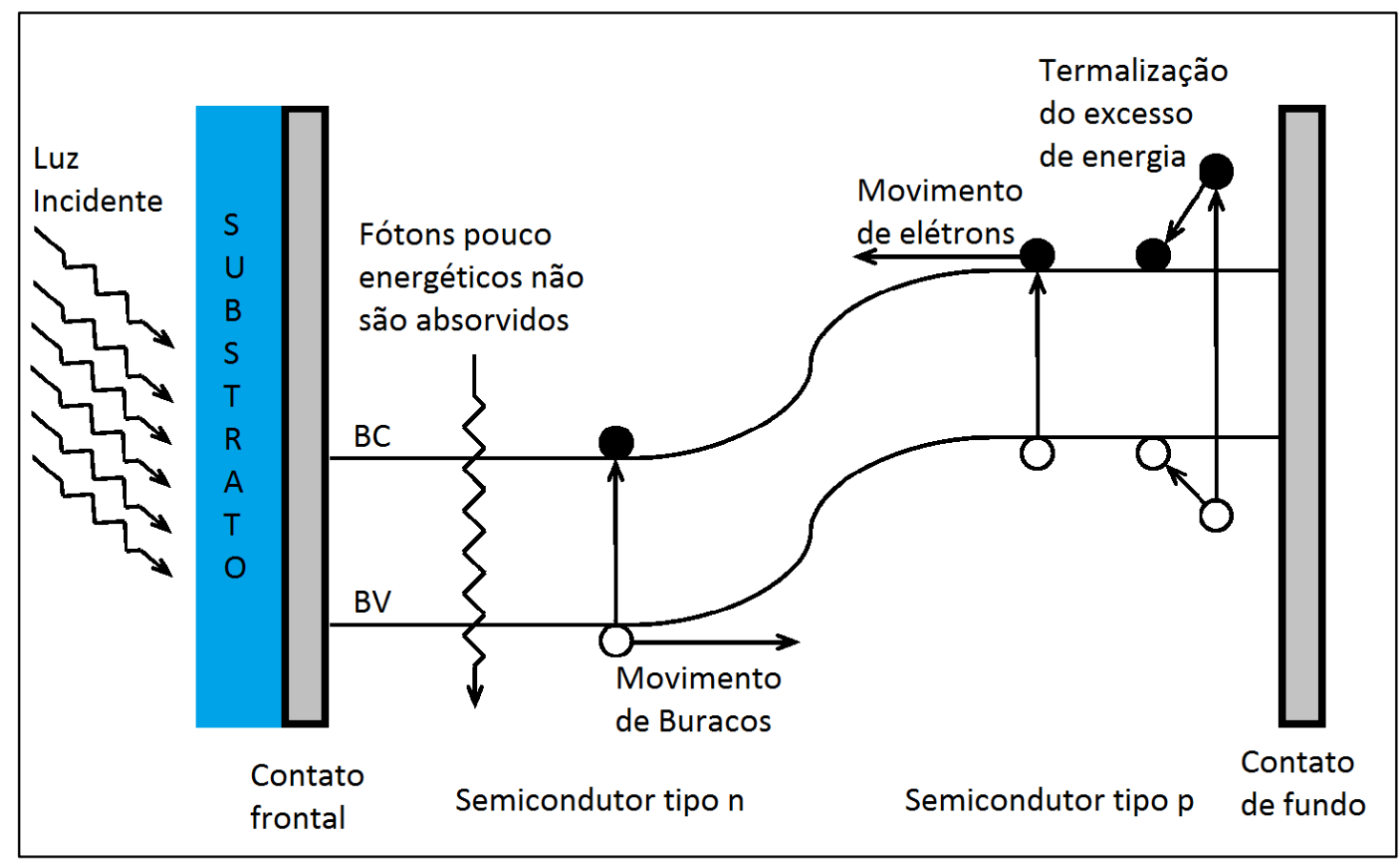

Figura 3.2.4 - Efeito fotovoltaico 
Quando fótons incidentes no material possuem energia igual ou superior que a largura da banda proibida do semicondutor, os elétrons da banda de valência, ao absorvê-los, adquirem energia suficiente para atingir a banda de condução, deixando buracos na banda de valência. Esse fenômeno é conhecido como fotogeração de pares elétron-buraco.

Ao ocorrer a formação de pares elétron-buraco na junção p-n, o campo elétrico da junção faz com que os portadores de carga se separem na direção dos contatos conforme a figura acima.

A coleta de elétrons no contato frontal e de buracos no contato de fundo estabelece uma diferença de potencial nos terminais da célula que é então usada como fonte de energia elétrica (Kasap, 2006).

Para obter o máximo de eficiência na conversão de energia luminosa em energia elétrica a célula solar deve ser otimizada. Primeiramente, a absorção de fótons deve ser a melhor possível, em especial em comprimentos de onda entre $390 \mathrm{~nm}$ e $700 \mathrm{~nm}$, ocorrendo o mínimo de perdas energéticas em função da recombinação dos portadores elétron-buraco. Além disso, as camadas frontais da célula (substrato, contato frontal e camada de janela) devem permitir a passagem dos fótons com o mínimo de absorção ou reflexão.

Essas são algumas das condições que determinam várias características que devem ser cuidadosamente refinadas na produção da célula, como materiais usados, tipos de deposição e tipos de processamento antes, durante e depois das deposições. Tudo influencia no rendimento final do dispositivo.

\section{3 Óxidos Condutores Transparentes}

Foi visto na figura 3.2.2 que uma célula solar de filme fino possui várias camadas. Neste trabalho, no entanto, somente o contato frontal foi colocado em foco. Mesmo assim, é necessário o entendimento do funcionamento da célula solar como um todo e de seus componentes, como já foi descrito, para compreender quais são as propriedades necessárias nesse contato frontal para um bom desempenho do dispositivo.

Como já foi visto anteriormente, fótons com energia inferior à largura da banda proibida não são absorvidos. Por isso, esses contatos são, em geral, 
semicondutores do tipo n com banda proibida acima de 3,0 eV, de forma a garantir que o mínimo de radiação eletromagnética dentro da região visível seja absorvida já que a absorção aconteceria em comprimentos de onda menores que 400nm.

Esta camada também constitui um dos contatos elétricos da célula solar, onde os elétrons fotogerados serão coletados e transmitidos para o circuito externo à célula solar, o que impõe que esta camada, além de possuir valores de transmitância acima de $80 \%$, também possua baixa resistividade elétrica (menor que $10^{-3} \Omega$.cm). Em geral, filmes de espessura abaixo de $300 \mathrm{~nm}$ são capazes de cumprir esses requisitos, levando em consideração que o aumento na espessura resulta tanto em uma diminuição da resistência quanto em uma diminuição da transmitância, o que torna necessária a otimização da espessura para cada tipo de TCO.

\subsection{Materiais utilizados como TCO}

O primeiro filme fino de TCO foi reportado por Badeker em 1907, há mais de 1 século. Filmes de CdO (óxido de cádmio) foram produzidos por oxidação térmica de filmes de cádmio $(\mathrm{Cd})$ metálico pulverizados. Enquanto $\mathrm{Cd}$ não é mais muito utilizado atualmente devido à sua conhecida toxicidade [8], ele se mantém como um interessante elemento devido a suas propriedades elétricas.

Décadas seguintes à descoberta do $\mathrm{CdO}$, avanços na tecnologia atraíram a atenção da indústria aeronáutica, que a partir dos anos 1940 (Bright, 2008), passou a investir na a aplicação de filmes aquecedores em desembaçadores de para-brisas. Nos anos seguintes, filmes de TCO avançaram muito devido à pesquisa e poderiam ser vistos em aparelhos do dia-a-dia como relógios digitais, telas de computadores e outros tipos de mostradores.

Nos dias de hoje, do ponto de vista comercial, o óxido de índio dopado com estanho (ITO) é o material mais utilizado como TCO. Ele possui valores bem baixos de resistividade como $1,29 \times 10^{-4} \Omega$.cm depositado sobre vidro (Tuna et al, 2010), por pulverização catódica. Além disso, esse filme apresenta elevada transmitância ótica (>85\%) para a região visível. As propriedades dos filmes óxidos dependem do estado de oxidação, da natureza e da quantidade de impurezas no filme.

Como parte do projeto de pesquisa do LFF/IME "Desenvolvimento de filmes finos transparentes para contatos fotovoltaicos: avaliação do uso em células solares 
flexíveis", muitos óxidos diferentes estão sendo testados e estudados para utilização como contatos frontais. Abaixo estão listadas algumas características destes materiais.

\subsection{1 $\mathrm{SnO}_{2}$}

O óxido de estanho foi o primeiro óxido condutor transparente a ter uma significante comercialização. O filme de $\mathrm{SnO}_{2}$ não dopado caracteriza-se por um semicondutor do tipo $\mathrm{n}$ devido a não estequiometria dos átomos constituintes, já que possui vacâncias de oxigênio (Cachet, 2005). Além disso, apresenta baixa resistividade elétrica $\left(1,67 \times 10^{-4} \Omega . \mathrm{cm}\right)$ e alta transparência na região visível do espectro eletromagnético (>85\%) (Manifacier et al, 1977). Essas propriedades fazem do $\mathrm{SnO}_{2}$ um bom candidato para utilização como TCO.

$\mathrm{O} \mathrm{SnO}_{2}$ possui a estrutura de bandas da figura 3.4.1. Analisando-a vemos que o "gap" é direto e de largura igual a 3,6eV (Robertson, 2010). As transições eletrônicas entre banda de valência e banda de condução podem se dar tanto de forma direta como de forma indireta. Isso será estudado mais a diante, no capítulo 4 , quando o assunto espectro de transmitância for abordado.

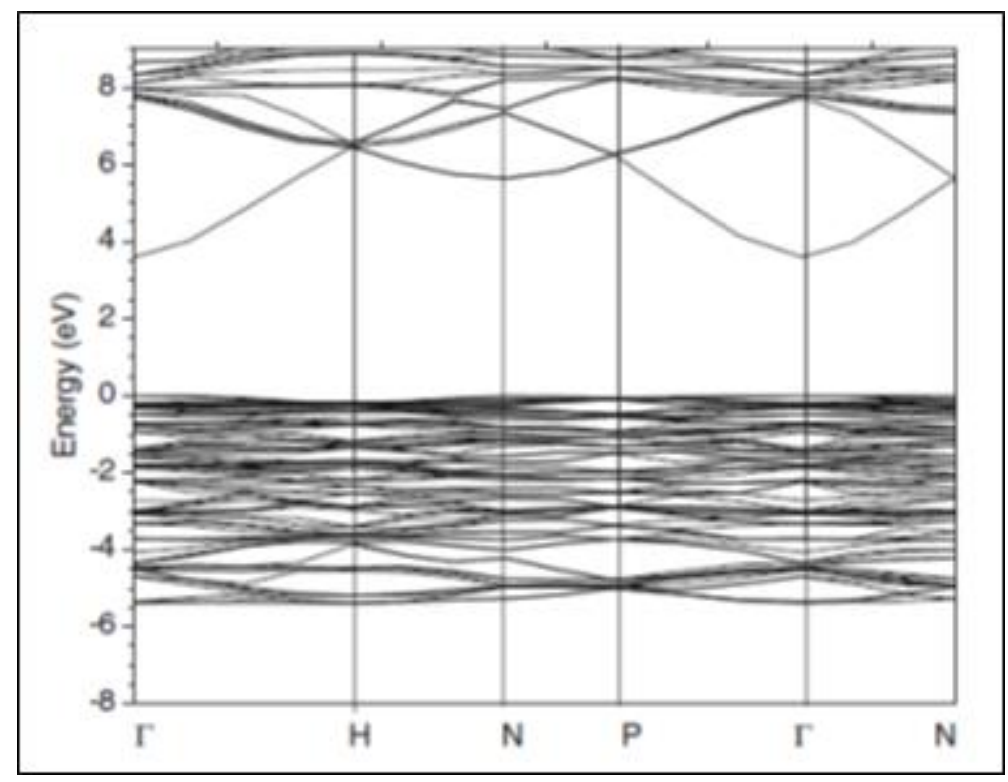

Figura 3.4.1 - Estrutura de bandas do $\mathrm{SnO}_{2}$ (Robertson, 2010) 


\subsubsection{ZnO e ZnO:Al}

Outro importante TCO é o óxido de zinco. Esse composto pode se cristalizar em três estruturas diferentes, o que varia o valor de seu Eg. Quando possui a estrutura da wurtzita, o ZnO possui banda direta e de valor 3,37 (Milão et al, 2011), mas quando na estrutura da blenda de zinco, possui "gap" direto de valor 3,35 (Robertson, 2010) como visto abaixo na figura 3.4.2.

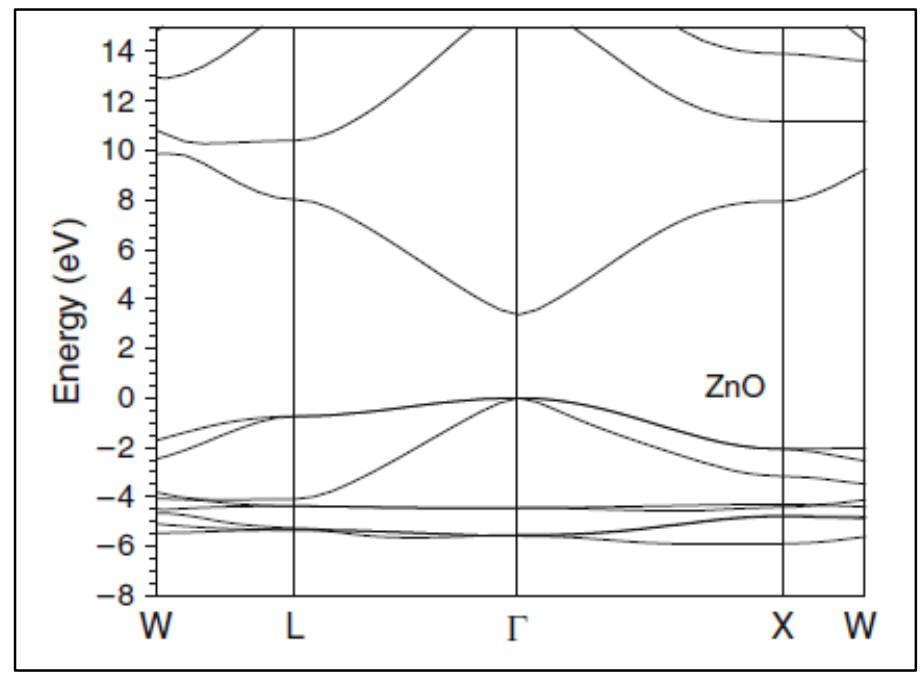

Figura 3.4.2 - Estrutuda de banda do ZnO cúbico (blenda de zinco) (Robertson, 2010)

Esse óxido apresenta diversas vantagens em relação aos outros pela combinação das seguintes propriedades: não toxicidade, boas características elétricas, óticas e piezoeletricas, além do baixo custo de obtenção (Seeber et al, 1999). Devido a sua alta transmitância óptica e baixa resistividade, filmes de óxido de zinco têm atraído a atenção especialmente para aplicações em dispositivos ópticos eletrônicos, materiais condutores transparentes e células solares.

É proposto que pequenas adições de alumínio (Al) possam melhorar as propriedades optoeletrônicas do TCO, sendo algo abordado nas pesquisas do LFF/IME. Já foram obtidos resultados de resistividade abaixo de $10^{-4} \Omega . \mathrm{cm}$ com transparência acima de 80\% no visível (Seeber et al, 1999 \& Gondoni et al, 2012). 


\subsection{3 $\quad \ln _{2} \mathrm{O}_{3}$}

O óxido de índio é um semicondutor do tipo $\mathrm{n}$ devido a variações da composição estequiométrica tendo excesso de átomos de índio ou vacâncias de oxigênio. Suas propriedades podem variar consideravelmente quando submetido à processos de fabricação distintos, sendo necessário grande refino dos parâmetros envolvidos (Beena et al, 2011).

O estudo do valor da banda proibida desse composto passou por várias conclusões diferentes ao longo dos anos, desde um Eg direto de valor 3,7 eV (Liu et al, 2008) a um Eg indireto de valor igual a 2,6 eV (Weiher, 1966). Estudos mais recentes concluíram que o valor mínimo para o Eg é de 2,9 eV e se dá por uma transição direta (Robertson, 2010), como visto na figura 3.4.3.

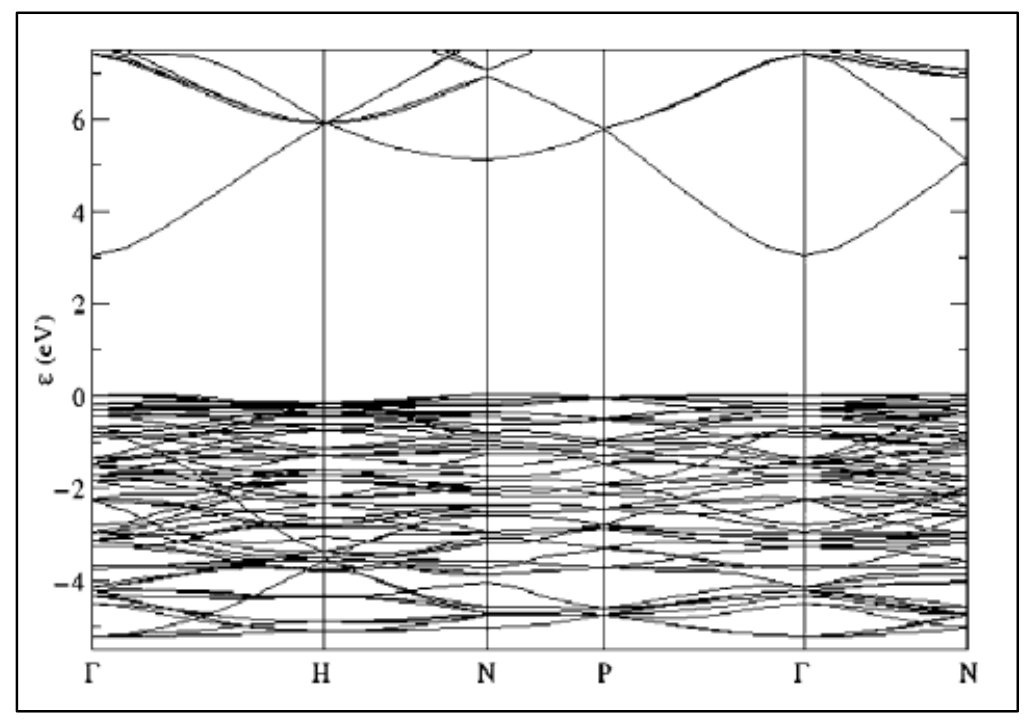

Figura 3.4.3 - Estrutura de bandas do $\mathrm{In}_{2} \mathrm{O}_{3}$ (Robertson, 2010)

É possível observar, portanto, como as propriedades dos compostos é modificada por pequenos detalhes podendo ser esperados valores muito distintos entre si nos resultados da pesquisa com $\mathrm{ZnO}$ ou $\mathrm{ZnO}: \mathrm{Al}$. 


\subsection{4 $\mathrm{Zn}_{2} \mathrm{SnO}_{4}$}

Filmes com dois elementos metálicos são geralmente produzidos a partir de dois óxidos precursores, sendo nesse caso o $\mathrm{ZnO}$ e o $\mathrm{SnO}$. Filmes de $\mathrm{Zn}_{2} \mathrm{SnO}_{4}$ (ZTO) apresentam transmitância acima de $80 \%$ e banda de absorção abaixo de $320 \mathrm{~nm}$, apesar de apresentarem resistividade na ordem de $10^{-2} \Omega . \mathrm{cm}$ (Enoki et al, 1992 \& Jin et al, 2003).

É proposto que o valor da banda proibida para esse tipo de composto seja em torno de 3,6-3,7 eV, comportando uma transição direta (Alpuche-Aviles, Wu, 2009). É importante ressaltar novamente que variações na estequiometria podem alterar o valor de Eg significantemente.

\subsection{5 $\mathrm{Cd}_{2} \mathrm{SnO}_{4}$}

Assim como o ZTO, os filmes de $\mathrm{Cd}_{2} \mathrm{SnO}_{4}$ (CTO) são geralmente fabricados a partir de $\mathrm{CdO}$ e $\mathrm{SnO}$. Embora ainda não sejam muito explorados comercialmente, apresentam elevado potencial elétrico e ótico como TCO. Filmes preparados por pulverização catódica apresentaram excelente transparência (80\% 90\%) e resistividade de $1,28 \times 10^{-4} \Omega . c m$ (Wu et al, 1996).

A banda proibida proposta para esse óxido é direta e possui valores entre 3,0 eV e 3,3 eV (Jeyadheepan et al, 2015). Isso só reforça a sua importância para aplicações como contatos frontais em células solares, já que fica com a banda de absorção em valores ótimos para permitir a passagem da radiação eletromagnética desejada.

\subsection{Métodos de fabricação de filmes finos TCO}

TCO podem ser fabricados a partir de MOCVD (deposição química em fase vapor de compostos organometálicos), MOMBD (deposição por feixe molecular de compostos organometálicos), spray pirólise, deposição química em fase líquida, dentre vários outros métodos. O método utilizado no LFF/IME é o de pulverização 
catódica com rádio frequência assistida por campo magnético, sendo realizado em um equipamento construído no próprio laboratório.

Na técnica de pulverização catódica, átomos ou moléculas são ejetados de uma fonte, denominada alvo, composta pelo material que se deseja depositar em cima do substrato. A ejeção ocorre devido ao bombardeamento da superfície do alvo por íons formados a partir de um plasma que é formado no interior de uma câmara de deposição.

O alvo, fixado em um eletrodo polarizado negativamente, é pulverizado pelos íons positivos que o atingem. Devido à energia cinética dos íons, ocorre o desprendimento de partículas do alvo durante a colisão. Logo, o princípio deste processo reside no choque físico ocorrendo troca de momento linear entre os íons ionizados do gás e os átomos constituintes do alvo.

Para aumentar o rendimento do processo escolhe-se, normalmente, o gás argônio para ser ionizado. Além disso, o equipamento usa um magneto sobre o alvo, de forma que o campo magnético aprisiona os elétrons no entorno do alvo, o que aumenta o processo de ionização do gás e a taxa de pulverização.

A figura 3.5.1 descreve esquematicamente o processo de deposição por pulverização catódica que foi utilizado na fabricação das amostras deste trabalho. Elas foram previamente fabricadas para diversas pesquisas do Laboratório e, agora, serão utilizadas neste projeto. Os processos e variáveis associadas à fabricação não serão detalhados, uma vez que já foram publicados em outros trabalhos, mas servirão a todo momento como referência para a análise dos resultados.

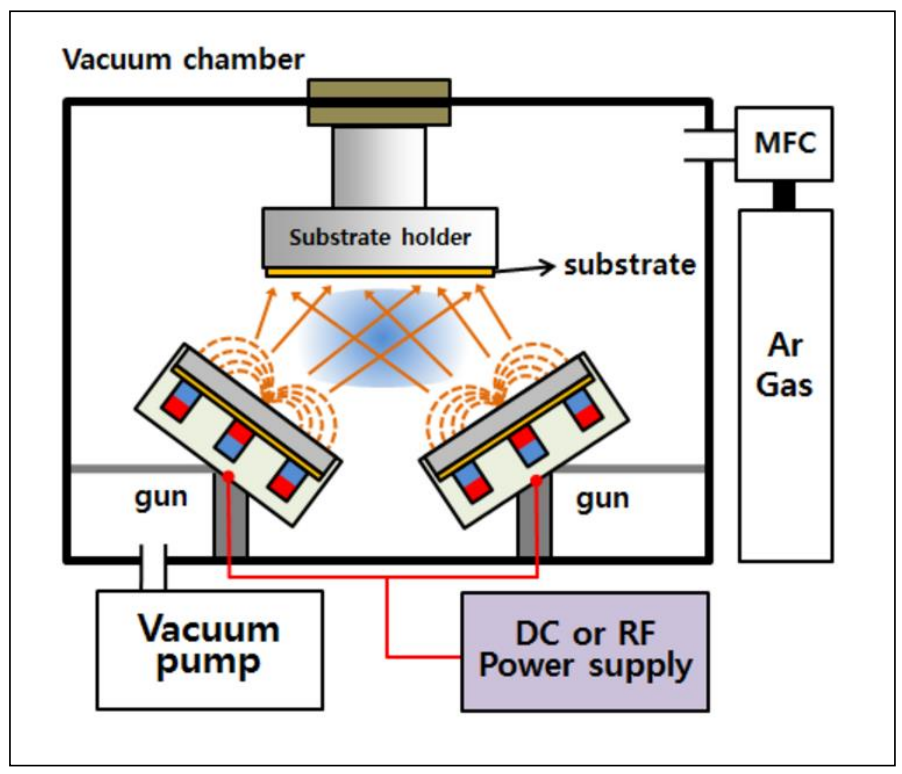

Figura 3.5.1 - Desenho esquemático da pulverização catódica (http://marriott.tistory.com/97) 


\section{Fundamentação Teórica}

Nesse capítulo estão descritos os fenômenos diretamente estudados nesse trabalho e os princípios físicos envolvidos, assim como uma descrição do funcionamento do principal equipamento de caracterização utilizado, o espectrofotômetro.

\subsection{O Espectrofotômetro e a radiação eletromagnética}

Cada composto químico absorve a luz (radiação eletromagnética) ao longo de um determinado intervalo de comprimentos de onda. Essa absorção foi pela primeira vez proposta por Einstein em 1905 quando deu origem ao conceito que viria a se tornar o que hoje chamamos de fóton. Desde então foram sendo descobertos vários mecanismos diferentes para a absorção de fótons por um material como, por exemplo, a já citada absorção de luz pelos semicondutores para a criação do par elétron-buraco.

Espectrofotometria é uma medição da quantidade que uma substância química absorve ou transmite luz e tem como objetivo saber exatamente como um determinado comprimento de onda da radiação eletromagnética interage com os átomos e moléculas. Atualmente, é amplamente utilizada para a análise quantitativa em química, física, biologia, materiais, engenharia, etc. Qualquer aplicação que lida com substâncias ou materiais químicos pode usar esta técnica. Na bioquímica, por exemplo, é usado para determinar as reações catalisadas por enzimas.

Para produzir os dados referentes às leituras desejadas, várias coisas precisam acontecer no interior do espectrômetro. Em primeiro lugar, uma fonte de luz gera luz numa faixa de comprimentos de onda. Cada fonte luminosa só é capaz de emitir em pequenas faixas com intensidade suficiente para ser utilizada na medida. Logo, várias fontes devem ser utilizadas, por isso vários espectrômetros com especificações diferentes existem. Eles podem ter mais ou menos sistemas para poderem varrer por faixas maiores ou menores, dependendo do tipo de estudo que está sendo realizado. Dois exemplos de tipos diferentes são descritos a seguir:

- Espectrofotômetro UV-visível: usa a luz sobre a faixa ultravioleta (185-400 nm) e faixa visível (400-700 nm) do espectro de radiação eletromagnética. 
- Espectrofotômetro IR: usa luz sobre a faixa do infravermelho $(700-15.000 \mathrm{~nm})$ do espectro de radiação eletromagnética.

Após a geração dos fótons, o aparelho irá garantir através do caminho ótico que feixes retilíneos e apenas com comprimentos de onda específicos chegue na amostra. Para isso, um monocromador é utilizado, como mostra a figura 4.1.1. Com o feixe monocromático já obtido, várias medidas diferentes podem ser realizadas pelo equipamento, mas apenas serão discutidos dois tipos: a transmitância (\%T) e a refletância (\%R), que são as medidas necessárias para calcular quanto é absorvido pela amostra.

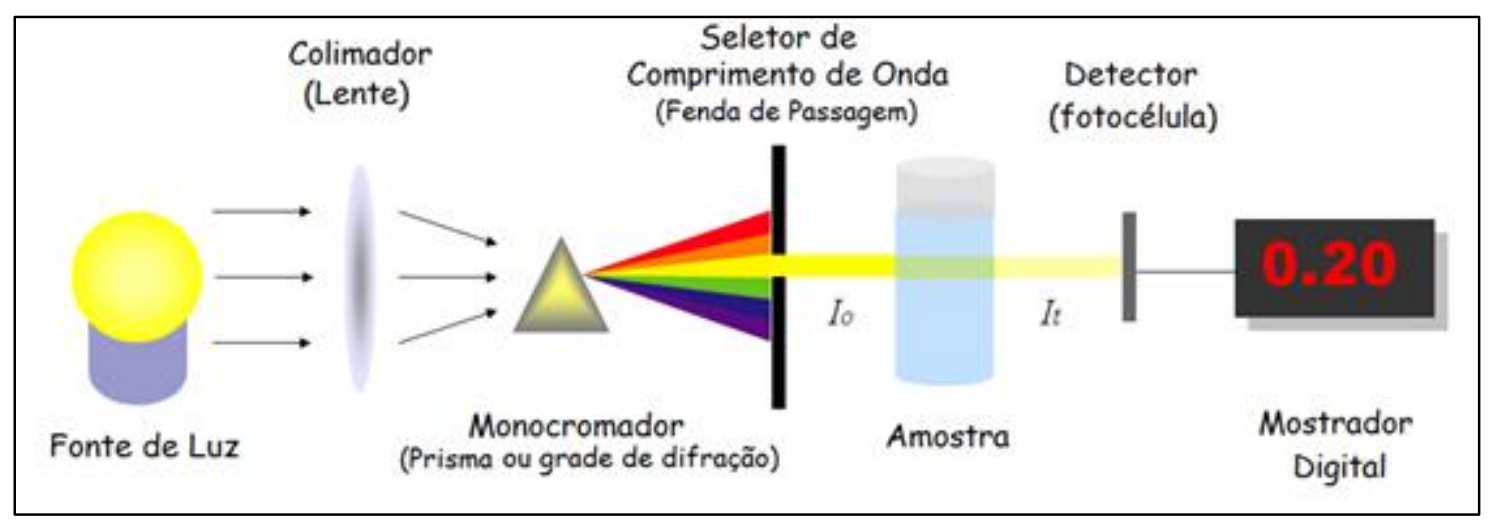

Figura 4.1.1 - Funcionamento de um espectrofotômetro (Adaptado de UC Davis, 2015)

A intensidade da absorção pode ser caracterizada pelo chamado coeficiente de absorção ótica do material ( $\alpha$ ), o qual é uma função do comprimento de onda da radiação, $\lambda$. Se uma radiação de intensidade $l_{0}$ incide sobre a superfície de um meio, a intensidade transmitida, I, através de uma espessura, $t$, pode ser obtida pela equação 4.1.1, conhecida como a lei de Lambert-Baer:

$$
I=I_{0} e^{-\alpha t}
$$

A transmitância do meio, $T$, é dada pela razão entre a intensidade da radiação transmitida e a radiação incidente:

$$
\mathrm{T}=\frac{\mathrm{I}}{\mathrm{I}_{0}}
$$

Quando a radiação eletromagnética troca de meio de propagação, por exemplo, ao sair do ar e entrar no vidro, ocorre a variação no índice de refração e isso 
gera um reflexo. Esse valor, definido por um percentual é chamado de $\mathrm{R}$, que é a razão entre a intensidade do feixe incidente $\left(\mathrm{I}_{0}\right)$ e a intensidade do feixe refletido $\left(\mathrm{I}_{\mathrm{R}}\right)$ :

$$
R=\frac{\mathrm{I}}{\mathrm{I}_{R}}
$$

Considerando que todas as medidas desse projeto foram feitas utilizando filmes depositados em substratos de vidro e apenas o conjunto substrato-filme foi analisado, podemos utilizar a seguinte relação para o cálculo do $\alpha$, sendo o índice $f, s$ correspondente ao conjunto e o índice $s$ referente ao substrato (vidro):

$$
\alpha=-\frac{1}{t} \ln \frac{T_{\mathrm{f}, \mathrm{s}}\left(1-R_{\mathrm{s}}\right)}{T_{\mathrm{s}}\left(1-R_{\mathrm{f}, \mathrm{s}}\right)}
$$

Logo, obtemos uma expressão para o cálculo da absorbância a partir das medidas de refletância e transmitância (Cruz et al, 2004).

\subsection{Análise dos espectros de Transmitância}

Para fins de estudo das propriedades optoeletrônicas dos TCO através de espectrofotometria, a faixa de 300-2300 nm do espectro eletromagnético foi analisada. Valores inferiores a $300 \mathrm{~nm}$ significam que o fóton incidente possui energia acima de 3,6 eV, o que é um valor maior que a banda de absorção do substrato de vidro utilizado; logo, é impossível obter qualquer informação do filme para energias superiores a essa.

Valores superiores a $2300 \mathrm{~nm}$ pouco importam para esse estudo devido à aplicação destinada desses filmes finos, já que células solares tem como objetivo absorver ondas próximas ao visível, entre 400nm e 800nm. Usualmente, a faixa de comprimentos de onda entre $800 \mathrm{~nm}$ e $2300 \mathrm{~nm}$ é pouco utilizada nos estudos, mas esse trabalho também visa obter análises qualitativas ao comparar medidas nessa faixa do espectro.

A partir do exemplo da Fig. 4.2.1, vemos as três regiões da radiação eletromagnética que serão estudadas independentemente. À esquerda, o ultravioleta, 
no meio, o visível e, à direita, o infravermelho. Cada uma possui informações diferentes sobre as propriedades optoeletrônicas que serão apresentadas a seguir.

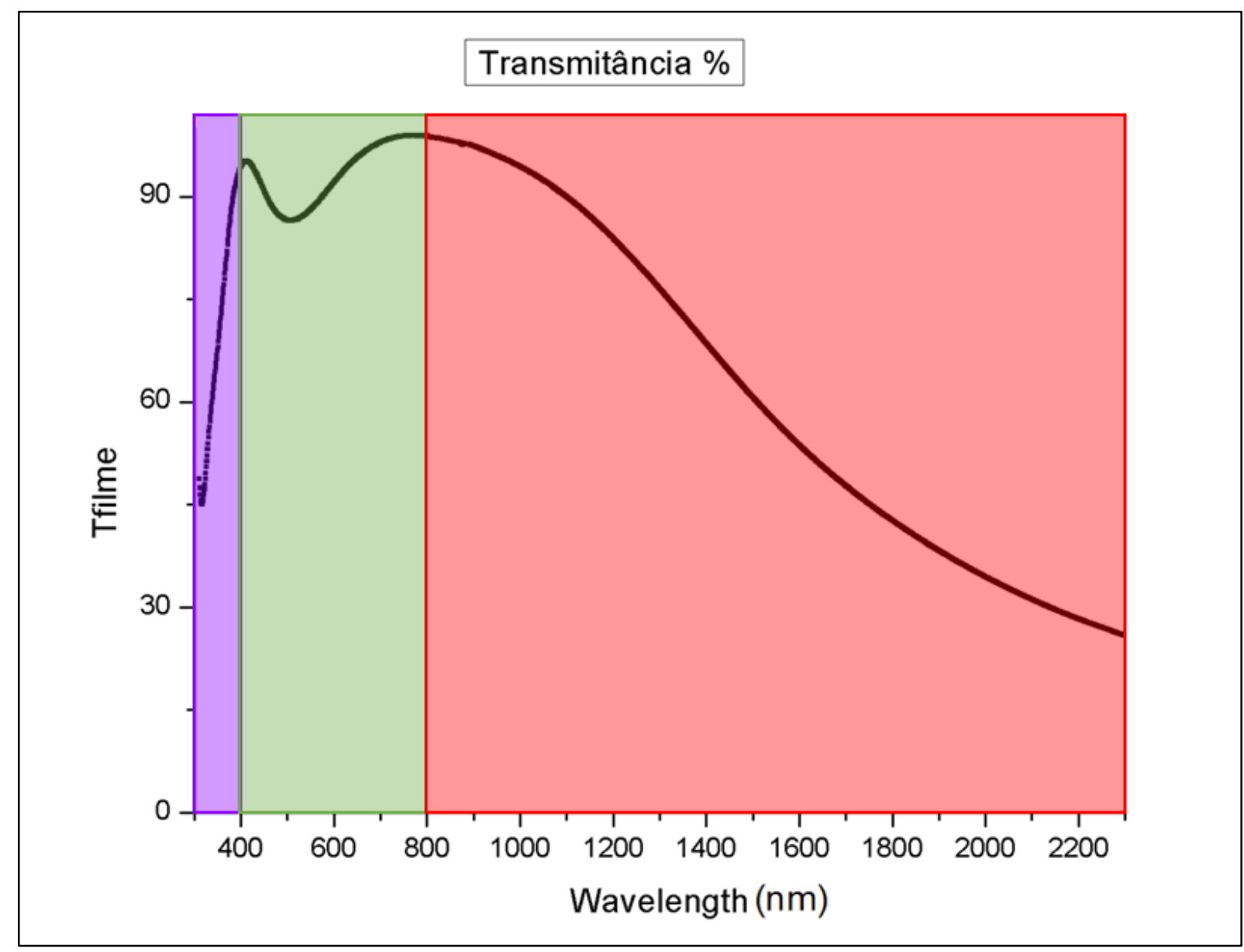

Figura 4.2.1 - Exemplo de espectro de transmitância

\subsubsection{Análise na região ultravioleta}

A absorção de fótons para a fotogeração de pares elétron-buraco requer que a energia do fóton incidente seja ao menos igual à largura da banda proibida Eg do semicondutor para que ocorra a excitação eletrônica da banda de valência (BV) para a banda de condução (BC), como visto na sessão 3.2. A seguir é apresentada a equação que define qual é o comprimento de onda máximo para que ocorra esse fenômeno.

$$
\lambda(\mathrm{nm})=\frac{1240}{E_{g}(\mathrm{eV})}
$$


Fótons incidentes com $\lambda$ menores que este são, portanto, absorvidos à medida que eles passam pelo material, o que nos faz retornar à equação 4.1.1 que define o coeficiente de absorção.

É mostrado na figura 4.2.2 que existem dois mecanismos possíveis de absorção: absorção direta e absorção indireta, como mencionado na sessão 3.4.1. Para o processo de absorção direta, um fóton é absorvido por um elétron da banda de valência do cristal, ocorrendo a criação de um par elétron-buraco. Nesse processo, a região do mínimo da banda de condução ocorre no mesmo valor do vetor de onda, $\mathrm{k}=1 / \lambda$, que o máximo da banda de valência, como visto na figura 4.2.2(a). Logo, ao passar da BV para a BC, o elétron não modifica seu momento e, dessa forma, as leis de conservação de energia e do vetor de onda são preservadas.

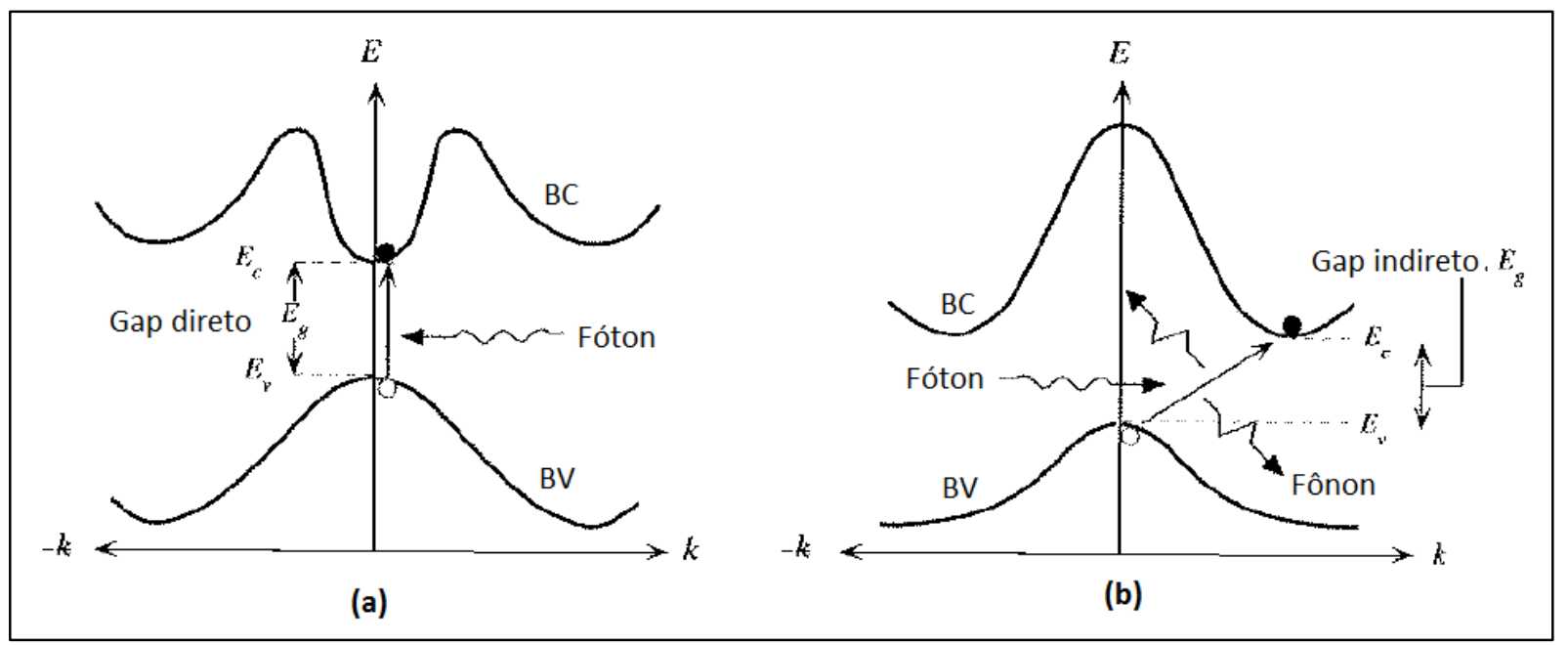

Figura 4.2.2 - Diagrama de transições eletrônicas entre BV e BC para absorções (a) direta e (b) indireta (Adaptado de Kasap, 2001)

Já para o processo de absorção indireta, o mínimo da BV e o máximo da BC estão separados por uma variação substancial no valor de k. Nesse caso, uma transição direta do elétron excitado não satisfaz a necessidade da conservação do vetor de onda. Logo, existe a necessidade de que uma contribuição externa (que não vem do fóton incidente) para as leis de conservação serem atendidas. Isso é obtido através das vibrações da estrutura do semicondutor, chamadas de fônons. Portanto, um fônon deve interferir para que haja a conservação de k. Cálculos mais específicos mostram que a energia desses fônons é bem menor que a dos fótons, estando entre aproximadamente 0,01 e 0,03 eV [26]. Outra característica importante é que as 
transições indiretas envolvem a absorção ou a emissão de um fônon, dependendo da intensidade da energia da radiação incidente.

O coeficiente de absorção para transições diretas está relacionado com a energia do fóton pelas expressões:

$$
\begin{gathered}
\alpha=c\left(h v-E_{g}\right)^{1 / 2} \\
\mathrm{e} \\
\alpha=c\left(h v-E_{g}\right)^{2}
\end{gathered}
$$

A primeira é a relação utilizada para transições diretas, enquanto a segunda é utilizada para transições indiretas. Pode-se traçar um gráfico de $\alpha^{2}$ e $\alpha^{1 / 2}$ em função de hv a partir das equações acima para obter o valor da banda proibida (Eg) direta ou indireta.

\subsubsection{Análise na região visível}

A análise dessa região visa, principalmente, saber se o TCO está desempenhando seu papel da forma esperada, ou seja, atuando como contato frontal de uma célula solar, deixando passar o máximo da radiação eletromagnética para as camadas subsequentes.

Esse valor é obtido sem muita complexidade calculando-se a média dos valores medidos dentro da faixa desejada, que nesse caso está entre 400 - $800 \mathrm{~nm}$.

Nessa região vemos, também, oscilações no espectro de transmitância. Essas oscilações são causadas por interferências construtivas e destrutivas entre as ondas eletromagnéticas dentro das amostras. O feixe incidente interage com as reflexões internas do material, gerando padrões que em amostras oticamente favoráveis podem ser utilizados para calcular o índice de refração e a espessura do filme (Manifacier et al, 1976). Nesse projeto, nenhuma das amostras analisadas apresentaram os padrões necessários (exemplificados na figura 4.2.3) para a realização desse tipo de medida. De qualquer jeito, esse fenômeno não será ignorado durante as análises. 


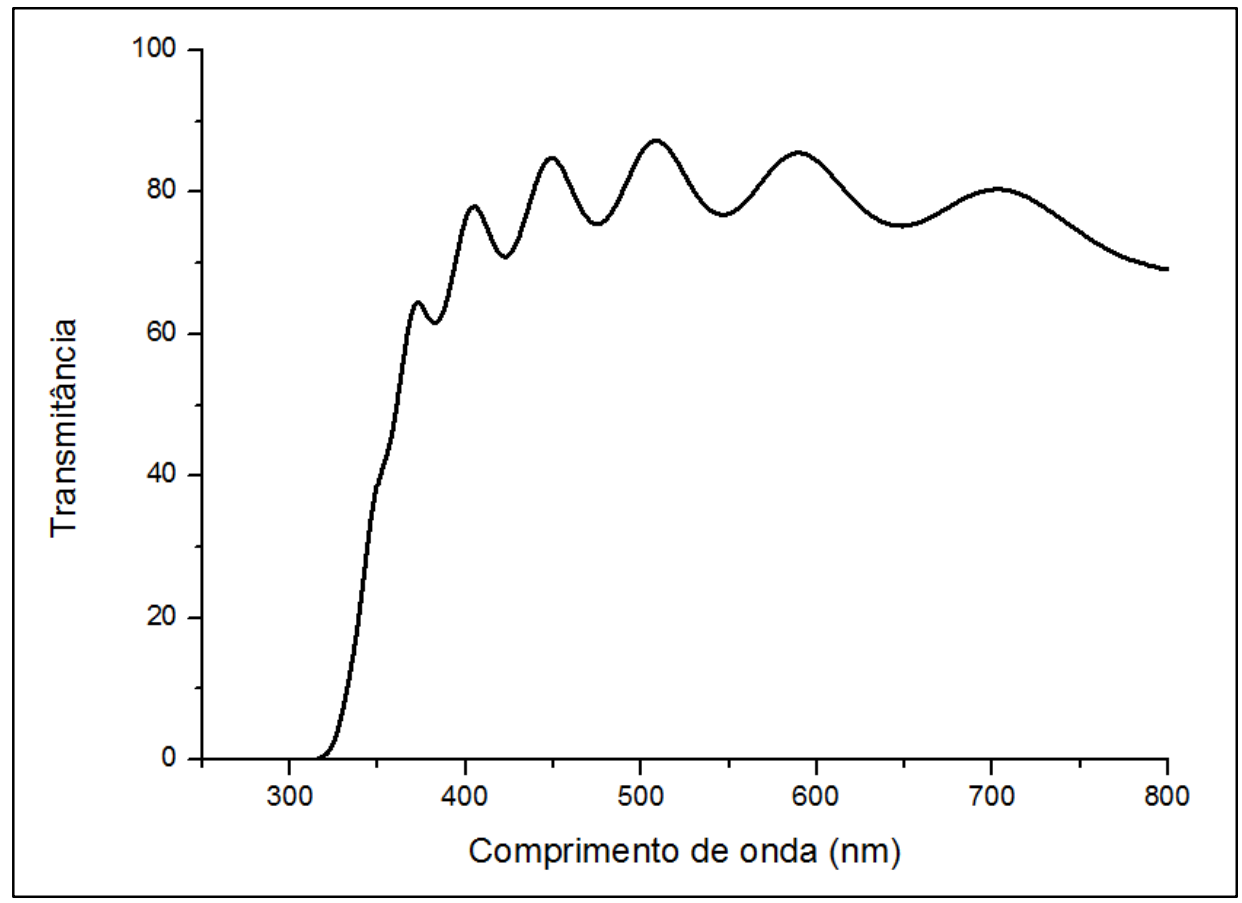

Figura 4.2.3 - Exemplo de espectro para cálculo de espessura e índice de refração

\subsubsection{Análise na região infravermelha}

Existem três tipos possíveis de absorção na região infravermelha: absorção eletrônica, absorção de rede ou por fônons e absorção por portadores (University of Reading, 2015). Para os TCO, a primeira ocorre na região ultravioleta, como já explicado na sessão 4.2.1. Já a absorção de rede ou por fônons ocorre na região da radiação infravermelha longa (5,6 - $1.000 \mu \mathrm{m})$, que não está sendo estudada. Portanto na região infravermelha analisada nesse projeto, apenas a absorção por portadores estará presente.

Na figura 4.2.4 a seguir, é possível ver a região onde ocorre a "Free carrier absorption", que em português significa "absorção por portadores livres". 


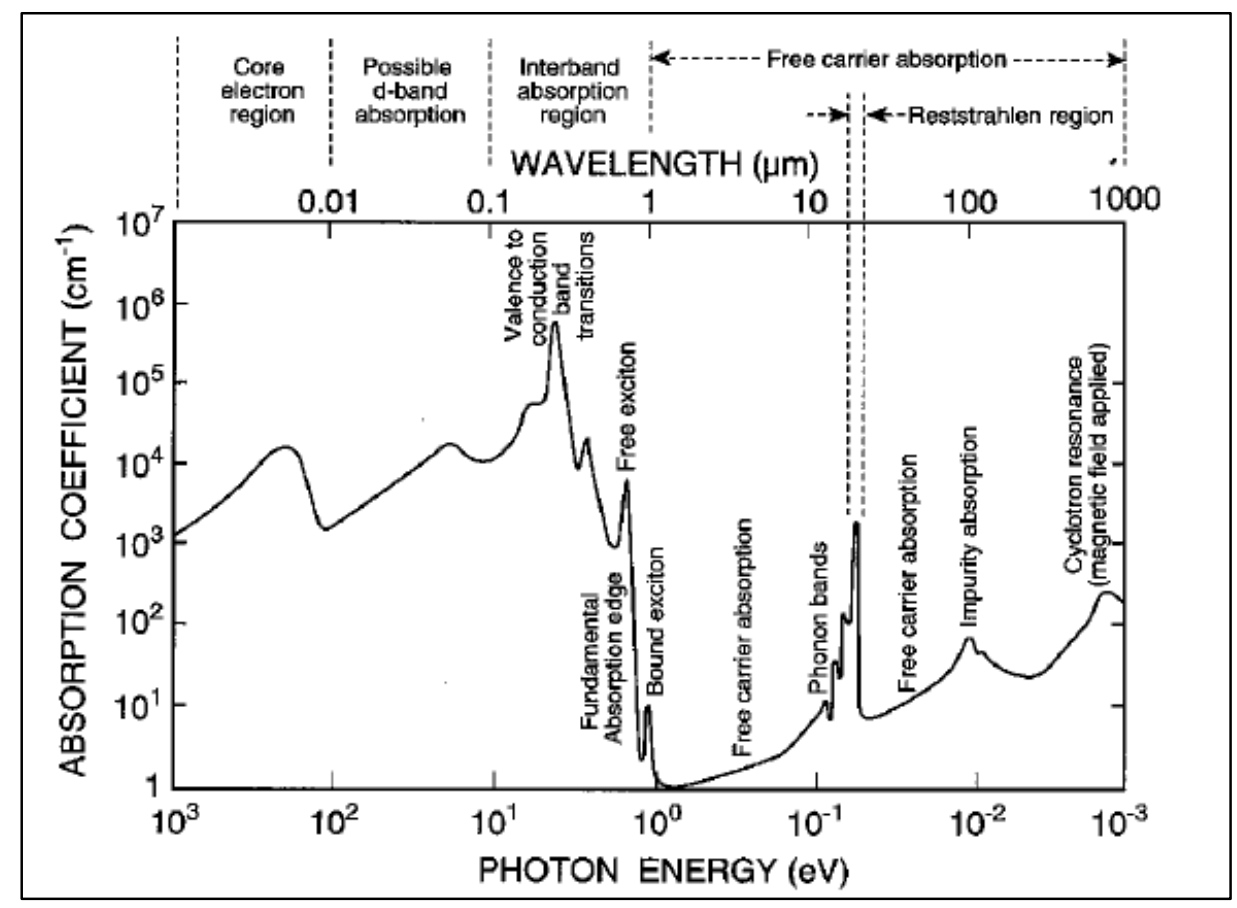

Figura 4.2.4 - Tipos de absorções em diferentes faixas de $\lambda$ (Amirtharaj, 1995)

Esse tipo de absorção envolve transições entre estados iniciais e finais dentro da mesma banda de energia, como visto na figura 4.2.5. Em semicondutores, elétrons livres e buracos podem contribuir para a absorção de radiação eletromagnética na região estudada, entre $800-2300 \mathrm{~nm}$, que aumenta à medida que o comprimento de onda aumenta. Pode-se concluir que é mais fácil ocorrer a absorção por portadores quando o fóton incidente possui energia menor, diminuindo a transmitância do material com o aumento do comprimento de onda.

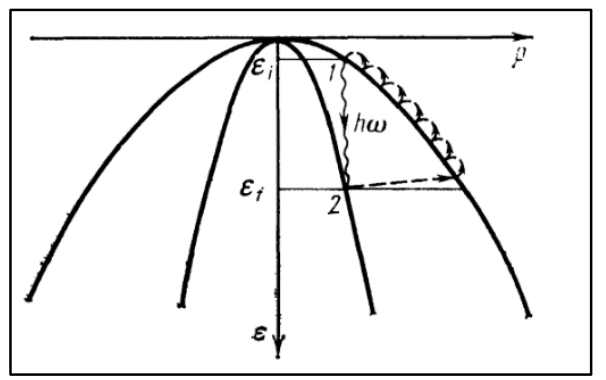

Figura 4.2.5 - Transições óticas e subsequente relaxação de energia dentro da banda de valência (Parshin, Shabaev, 1987) 


\section{Materiais e Métodos}

\subsection{Amostras utilizadas}

Todas as amostras analisadas foram fabricadas no Laboratório de Filmes Finos do Instituto Militar de Engenharia pelo método de pulverização catódica com rádio frequência assistida por campo magnético. A tabela 5.1.1 lista todas as amostras utilizadas e os principais parâmetros de deposição. A pressão de deposição foi a mesma para todas as amostras, em torno de 1 mTorr.

Tabela 5.1.1 - Amostras analisadas e seus dados de deposição

\begin{tabular}{|c|c|c|c|c|}
\hline Material & $\#$ & Data & Potência (W) & Tempo (s) \\
\hline $\mathrm{SnO}_{2}$ & 1 & $25 / 02 / 2015$ & 70 & 1444 \\
\hline $\mathrm{SnO}_{2}$ & 2 & $25 / 02 / 2015$ & 70 & 1413 \\
\hline $\mathrm{SnO}_{2}$ & 3 & $11 / 02 / 2015$ & 70 & 1440 \\
\hline $\mathrm{SnO}_{2}$ & 4 & $03 / 03 / 2015$ & 85 & 1086 \\
\hline $\mathrm{SnO}_{2}$ & 5 & $09 / 03 / 2015$ & 50 & 2395 \\
\hline $\mathrm{ZnO}$ & 1 & $09 / 12 / 2014$ & 95 & 2858 \\
\hline $\mathrm{ZnO}-\mathrm{Al}$ & 2 & $15 / 11 / 2014$ & --- & 4210 \\
\hline $\mathrm{ZnO}-\mathrm{Al}$ & 3 & $27 / 11 / 2014$ & 85 & 3090 \\
\hline $\mathrm{In}_{2} \mathrm{O}_{3}$ & 1 & $06 / 01 / 2015$ & 40 & 2220 \\
\hline $\mathrm{In}_{2} \mathrm{O}_{3}$ & 2 & $07 / 01 / 2015$ & 60 & 1325 \\
\hline $\mathrm{In}_{2} \mathrm{O}_{3}$ & 3 & $10 / 03 / 2015$ & 75 & 1028 \\
\hline $\mathrm{In}_{2} \mathrm{O}_{3}$ & 4 & $23 / 02 / 2015$ & 40 & 2261 \\
\hline $\mathrm{In}_{2} \mathrm{O}_{3}$ & 5 & $24 / 02 / 2015$ & 40 & 2268 \\
\hline $\mathrm{Zn}_{2} \mathrm{SnO}_{4}$ & 1 & $18 / 03 / 2015$ & 60 & 1800 \\
\hline $\mathrm{Zn}_{2} \mathrm{SnO}_{4}$ & 2 & $23 / 03 / 2015$ & 80 & 1490 \\
\hline $\mathrm{Cd}_{2} \mathrm{SnO}_{4}$ & 1 & $03 / 11 / 2014$ & 60 & 1380 \\
\hline $\mathrm{Cd}_{2} \mathrm{SnO}_{4}$ & 2 & $04 / 11 / 2014$ & 45 & 2100 \\
\hline $\mathrm{Cd}_{2} \mathrm{SnO}_{4}$ & 3 & $10 / 11 / 2014$ & 60 & 1348 \\
\hline $\mathrm{Cd}_{2} \mathrm{SnO}_{4}$ & 4 & $30 / 12 / 2014$ & 60 & 1360 \\
\hline
\end{tabular}




\subsection{Caracterização dos filmes finos}

\subsubsection{Espectroscopia ótica UV-VIS-IV}

O espectrofotômetro modelo CARY 5000, da Varian, pertencente ao LFF/IME, foi utilizado para obter os espectros de transmitância de todos os filmes estudados.

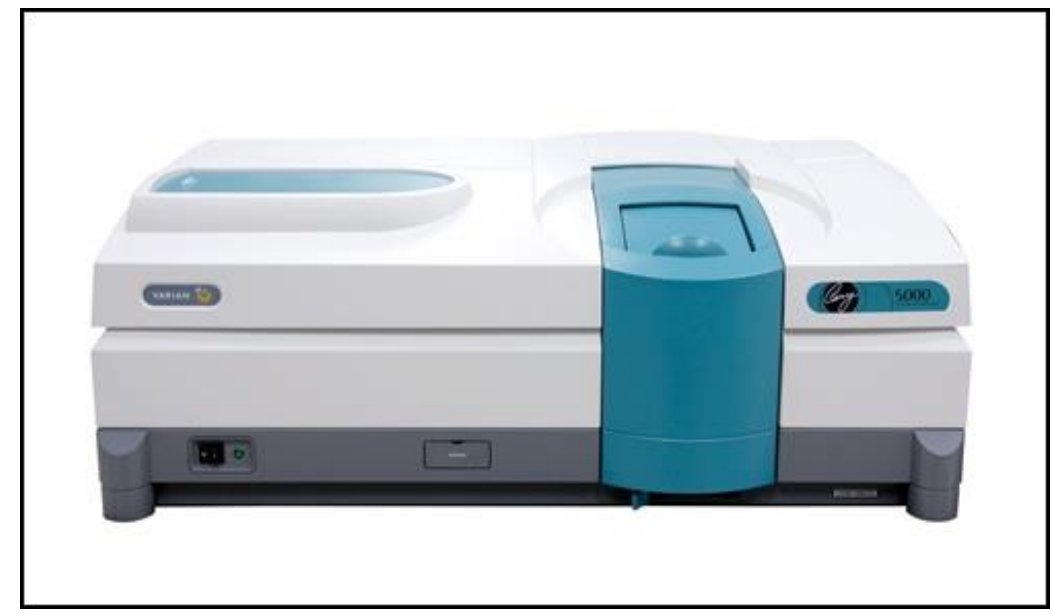

Figura 5.2.1 - Espectrofotômetro Varian Cary 5000

\subsubsection{Perfilometria}

A medida da espessura dos filmes foi realizada no LFF/IME no perfilômetro Dektak 150, da Veeco. Este equipamento é capaz de detectar variações na espessura de $100 \AA$ a 655 kÅ, com resolução de $10 \AA$.

Seu funcionamento se baseia na varredura unidimensional da superfície amostrada por uma ponta de diamante com diâmetro de 12,5 $\mu \mathrm{m}$ e peso variável de $1 \mathrm{~g}$ a $15 \mathrm{~g}$. As variações verticais da superfície são captadas e transmitidas para um transformador linear diferencial variável, que converte o deslocamento mecânico em um pulso eletrônico.

Para que sejam possíveis medidas de espessura através do perfilômetro, é necessário que se fabrique um degrau entre a superfície do filme e do substrato. Para isso, foram coladas finas tiras de fita kapton antes da deposição. Essas tiras, então, foram retiradas deixando no lugar delas áreas sem deposição de filme, permitindo a análise de degraus em regiões ao longo do substrato. 


\subsubsection{Resistividade}

A caracterização elétrica dos filmes foi realizada no LFF/IME em um equipamento desenvolvido pela BIO-RAD, o "Hall Effect Measurement System HL 5500", que utiliza o método Van der Pauw. As medidas são coletadas em um computador e anotadas.

Dentre as geometrias sugeridas para as amostras, mostradas na figura 5.2.2, foi necessário utilizar-se de duas: a em quadrado e a em trevo. Algumas amostras não haviam sido depositadas com a máscara para caracterização em trevo, o que seria o ideal. Para contornar essa dificuldade, pequenas quantidades de índio foram colocadas nas amostras para formar a geometria quadricular.

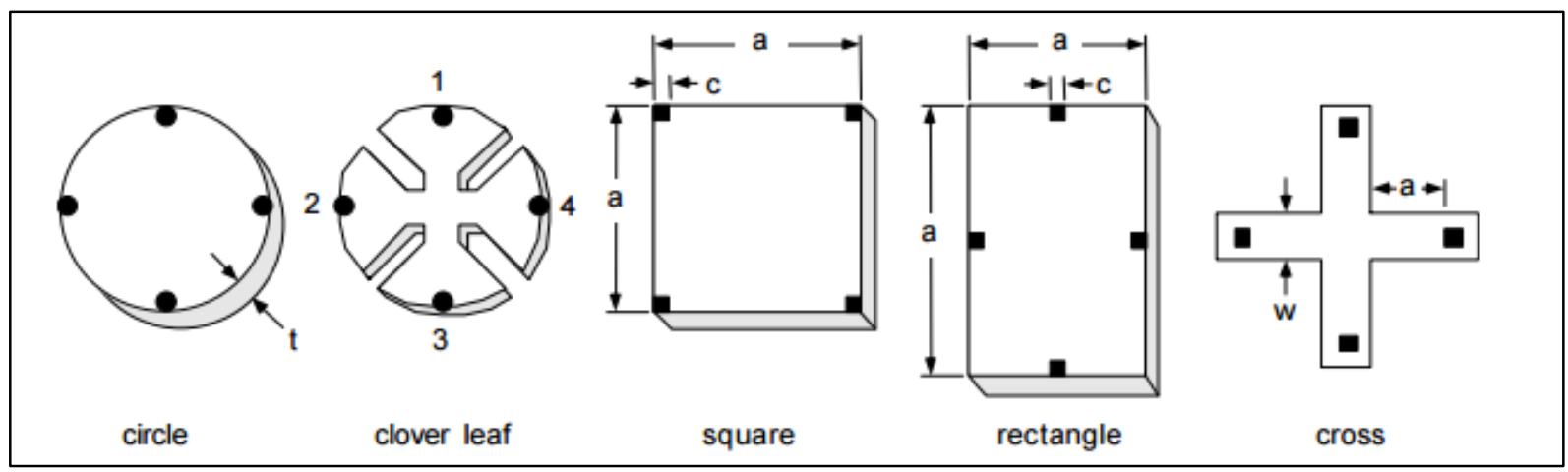

Figura 5.2.2 - Geometrias comuns de amostras para o método Van der Pauw (Lake Shore Manual) 


\section{Resultados e Discussão}

As dezenove amostras estudadas de cinco tipos diferentes de TCO foram caracterizadas obtendo-se valores de espessura, resistividade e transmitância.

A refletância também foi inicialmente medida para algumas amostras, porém os valores médios obtidos estavam em torno de $5 \%$ para o conjunto filme-vidro, enquanto que para o vidro estavam apenas em torno de 6\%. Embora esta diferença possa ser atribuída a erro experimental, vale a pena considerar a hipótese de que o filme tenha ajudado a diminuir a refletância e, por isso, como não há refletância negativa, os valores calculados para a refletância do filme não foram levados em consideração nos cálculos da equação 4.1.4, podendo ser simplificados pela equação 6.0.1:

$$
\alpha=-\frac{1}{t} \ln \frac{T_{\mathrm{f}, \mathrm{s}}}{T_{\mathrm{s}}}
$$

Apesar disso, como ocorreu uma diminuição da refletância, o filme poderia estar interferindo de duas formas. A primeira é como absorvedor das ondas incidentes em que a absorção seria responsável pela diminuição da refletância. Se esse fosse o caso, para comprimentos de onda abaixo de $300 \mathrm{~nm}$, na qual a absorção do filme seria de $100 \%$, veríamos uma intensa redução da refletância, o que não ocorreu. Por isso, a segunda interpretação é a mais creditada: os filmes estariam agindo como atenuadores de reflexão. Em outras palavras, como visto na sessão 4.1, a variação do índice de refração do meio é um dos causadores da reflexão e quanto maior essa diferença, maior é a reflexão, e vice-versa. Logo, a reflexão menor estaria associada a um índice de refração intermediário entre o vidro e o ar, favorecendo a passagem dos raios luminosos e, assim, aumentando a transmitância do conjunto. 


\subsection{Medidas elétricas e físicas}

Na tabela 6.1.1 são apresentados os valores obtidos para espessura e para a resistividade dos filmes. A partir dos valores de espessura, foi calculada a taxa de deposição tendo em base o tempo de deposição de cada uma.

Tabela 6.1.1 - Amostras analisadas e algumas medidas

\begin{tabular}{|c|c|c|c|c|}
\hline Material & $\#$ & Espessura $(\AA)$ & Taxa $(\AA / s)$ & Resistividade $\left(\Omega^{*} \mathrm{~cm}\right)$ \\
\hline $\mathrm{SnO}_{2}$ & 1 & 1550 & 1,07 & ${ }^{* * *}$ \\
\hline $\mathrm{SnO}_{2}$ & 2 & 1530 & 1,08 & $2,90 \mathrm{E}-03$ \\
\hline $\mathrm{SnO}_{2}$ & 3 & 1520 & 1,06 & $2,80 \mathrm{E}-03$ \\
\hline $\mathrm{SnO}_{2}$ & 4 & 1560 & 1,44 & $3,10 \mathrm{E}-03$ \\
\hline $\mathrm{SnO}_{2}$ & 5 & 1560 & 0,65 & $>1 \mathrm{M}$ \\
\hline $\mathrm{ZnO}$ & 1 & 1570 & 0,55 & $1,00 \mathrm{E}-03$ \\
\hline $\mathrm{ZnO}-\mathrm{Al}$ & 2 & 2950 & 0,70 & $8,60 \mathrm{E}-04$ \\
\hline $\mathrm{ZnO}-\mathrm{Al}$ & 3 & 2160 & 0,70 & $3,40 \mathrm{E}-04$ \\
\hline $\mathrm{In} 2 \mathrm{O}_{3}$ & 1 & 1340 & 0,60 & $2,40 \mathrm{E}-04$ \\
\hline $\mathrm{In}_{2} \mathrm{O}_{3}$ & 2 & 1020 & 0,77 & $4,00 \mathrm{E}-04$ \\
\hline $\mathrm{In}_{2} \mathrm{O}_{3}$ & 3 & 1660 & 1,62 & $* * *$ \\
\hline $\mathrm{In}_{2} \mathrm{O}_{3}$ & 4 & 1490 & 0,66 & $* *$ \\
\hline $\ln _{2} \mathrm{O}_{3}$ & 5 & 1510 & 0,66 & $9,10 \mathrm{E}-01$ \\
\hline $\mathrm{Zn}_{2} \mathrm{SnO}_{4}$ & 1 & 1500 & 0,83 & $2,10 \mathrm{E}+00$ \\
\hline $\mathrm{Zn}_{2} \mathrm{SnO}_{4}$ & 2 & 1770 & 1,19 & $9,70 \mathrm{E}-04$ \\
\hline $\mathrm{Cd}_{2} \mathrm{SnO}_{4}$ & 1 & 2050 & 1,49 & $1,30 \mathrm{E}-03$ \\
\hline $\mathrm{Cd}_{2} \mathrm{SnO}_{4}$ & 2 & 1950 & 0,93 & $9,30 \mathrm{E}-04$ \\
\hline $\mathrm{Cd}_{2} \mathrm{SnO}_{4}$ & 3 & 2040 & 1,51 & \\
\hline $\mathrm{Cd}_{2} \mathrm{SnO}_{4}$ & 4 & 2180 & 1,60 & \\
\hline & & & & \\
\hline
\end{tabular}

Os valores obtidos de resistividade são os primeiros a serem analisados. Vemos que os filmes de $\ln _{2} \mathrm{O}_{3}, \mathrm{Cd}_{2} \mathrm{SnO}_{4}$ e $\mathrm{ZnO}$ :Al possuem valores dentro da faixa de resistividade ideal para serem utilizados como contatos frontais em células solares. Destacam-se os filmes de $\ln _{2} \mathrm{O}_{3}$ que apresentaram os menores valores de resistividade.

Resta agora saber se as propriedades óticas também são ideais, uma vez que a resistividade aumenta com a espessura, enquanto a transmitância diminui.

Além disso, a resistividade servirá como comprovante na análise do número de portadores, já que os TCO são menos resistivos se possuírem mais portadores. 


\subsection{Medidas de transmitância}

As medidas de transmitância só puderam ser realizadas no conjunto vidrofilme, visto que não era possível separar apenas o filme. Portanto, para a obtenção da transmitância do filme sem a influência do vidro, uma simples conta de divisão é realizada, já que a transmitância do filme é igual à transmitância do conjunto dividida pela transmitância do vidro. Esses valores são vistos no exemplo mostrado na figura 6.2.1.

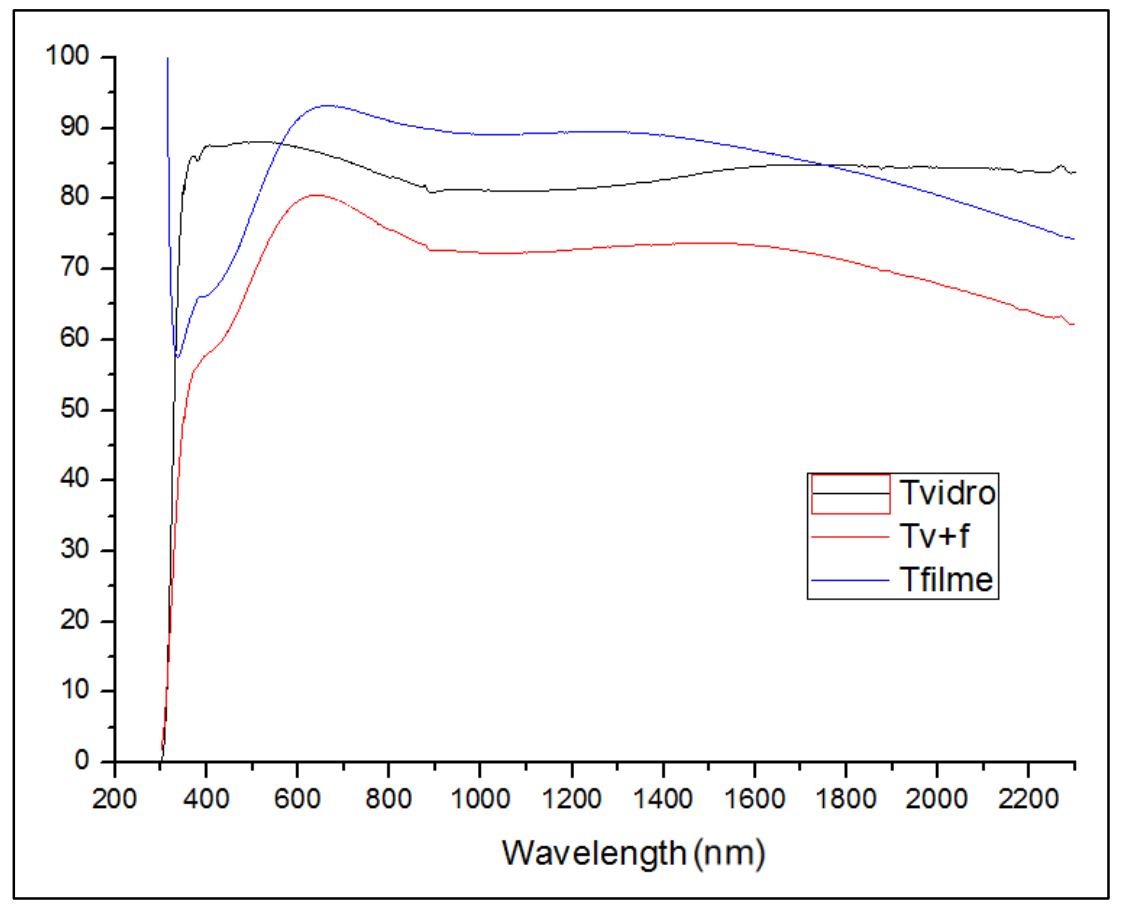

Figura 6.2.1 - Transmitâncias medidas do vidro, do conjunto vidro-filme e a transmitância calculada para apenas o filme. Espectros referente à amostra $\mathrm{SnO}_{2} \# 1$ e à um vidro padrão.

Pode-se observar que em torno de $330 \mathrm{~nm}$ a transmitância do filme começa a subir. Isso é uma consequência da divisão mencionada acima na região de alta absorção. Logo, para que a análise gráfica não seja prejudicada, os espectros a seguir serão todos cortados a partir do crescimento do valor da transmitância do filme, ou seja, no caso do filme $\mathrm{SnO}_{2} \# 1$, o gráfico será traçado no intervalo $337-2300 \mathrm{~nm}$. 


\subsection{1 $\mathrm{SnO}_{2}$}

A Fig. 6.2.2 mostra os espectros de transmitância dos filmes de $\mathrm{SnO}_{2}$.

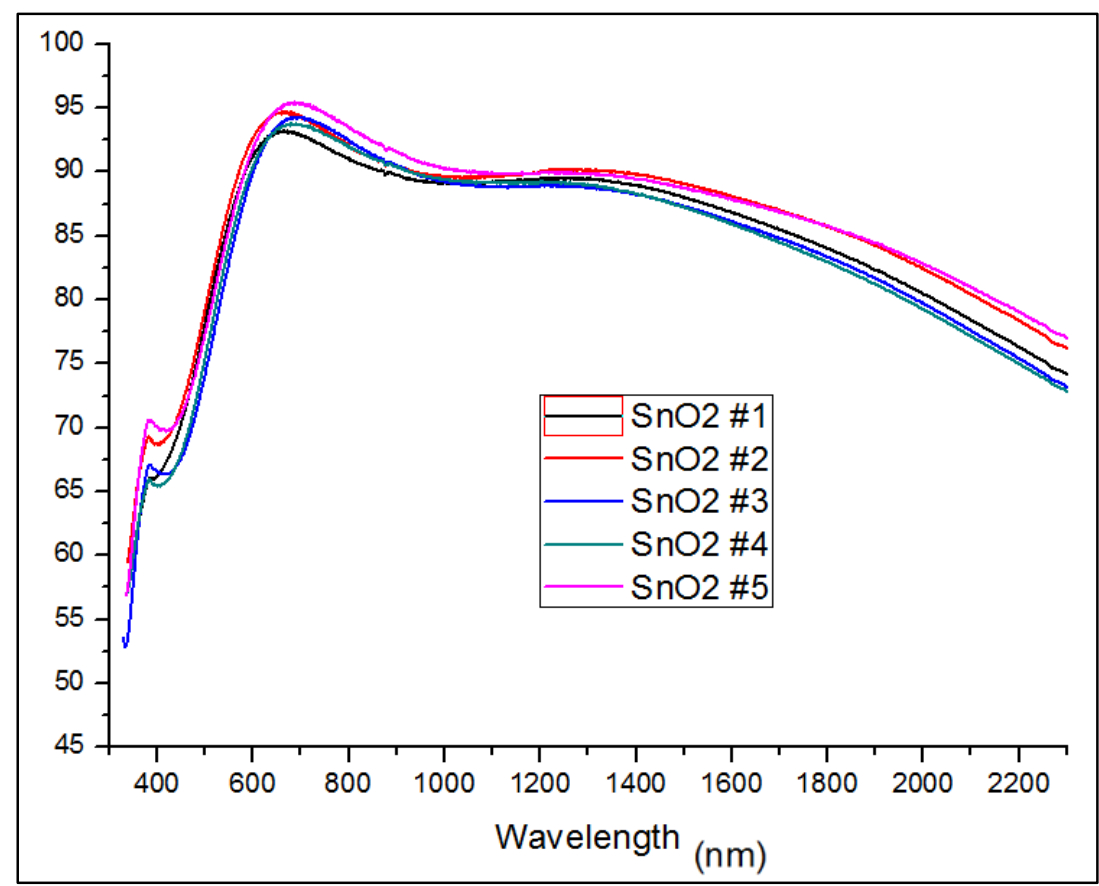

Figura 6.2.2 - Transmitâncias das amostras de $\mathrm{SnO}_{2}$

Começando a análise pela região ultravioleta, identificou-se a região de absorção para obtenção dos valores de Eg para cada filme. Para isso, foi calculado o coeficiente de absorção, $\alpha$, segundo a equação 4.2.2 e traçados os gráficos de $\alpha^{2}$ vs. energia.

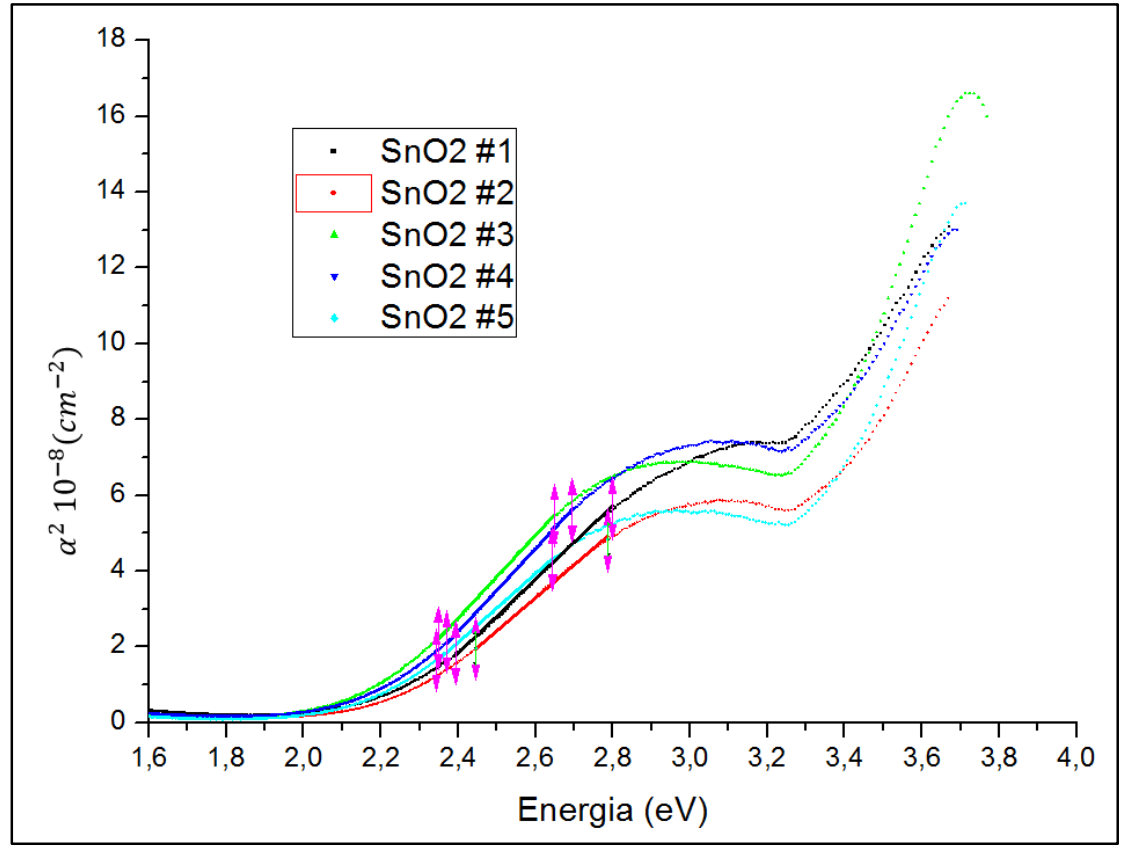

Figura 6.2.3 - Gráfico $\alpha^{2}\left(\mathrm{~cm}^{-2}\right)$ vs. hv (eV) das amostras de $\mathrm{SnO}_{2}$ 
É possível ver no gráfico a região de absorção. A partir dela é possível obter o valor de Eg, já que pela equação 4.2.2, fazendo $\alpha^{2}=0$, obtemos que Eg = hv. Esta expressão só é válida na região de absorção fundamental. Vale lembrar que na sessão 3.4.1 foi mostrado que esse material possui gap direto com valores em torno de 3,6 $\mathrm{eV}$. Os valores de Eg calculados foram:

\begin{tabular}{|c|c|c|}
\hline Material & $\#$ & $\mathrm{Eg}(\mathrm{eV})$ \\
\hline $\mathrm{SnO}_{2}$ & 1 & 2,204 \\
\hline $\mathrm{SnO}_{2}$ & 2 & 2,222 \\
\hline $\mathrm{SnO}_{2}$ & 3 & 2,147 \\
\hline $\mathrm{SnO}_{2}$ & 4 & 2,180 \\
\hline $\mathrm{SnO}_{2}$ & 5 & 2,166 \\
\hline
\end{tabular}

Tabela 6.2.1 - Valores de Eg dos filmes de $\mathrm{SnO}_{2}$

Os valores diferem bastante do valor teórico. Isso pode ser atribuído a vários fatores, dentre eles, o desvio da composição estequiométrica, a presença de defeitos na estrutura cristalina e a temperatura na qual o material foi medido. No entanto, o mais provável é que o substrato (vidro) tenha mascarado a região de absorção do filme devido à proximidade das bandas. Isto pode ser constatado na Fig. 6.2.1, que mostra que a absorção do vidro ocorre em $300 \mathrm{~nm}$, muito próximo à do $\mathrm{SnO}_{2}$. Para fazer estas medidas de absorção, teria sido importante utilizar um substrato diferente do vidro comum, tal como o de quartzo, cuja absorção ocorre bem abaixo de $300 \mathrm{~nm}$.

Prosseguindo a análise agora na região visível, vemos que em torno de $700 \mathrm{~nm}$ a transmitância chegou a ser superior a $90 \%$. Vale ressaltar que todas as amostras aqui estudadas possuem espessuras muito similares e portanto as transmitâncias também são similares. Os valores de transmitância na faixa 400-800 nm foram:

\begin{tabular}{|c|c|c|}
\hline Material & $\#$ & $\% \mathrm{~T}$ \\
\hline $\mathrm{SnO}_{2}$ & 1 & 85,30 \\
\hline $\mathrm{SnO}_{2}$ & 2 & 86,70 \\
\hline $\mathrm{SnO}_{2}$ & 3 & 84,50 \\
\hline $\mathrm{SnO}_{2}$ & 4 & 84,60 \\
\hline $\mathrm{SnO}_{2}$ & 5 & 86,50 \\
\hline
\end{tabular}

Tabela 6.2.2 - Valores de \% $\mathrm{T}$ no visível dos filmes de $\mathrm{SnO}_{2}$ 
Com transmitâncias em torno de $85 \%$ esse material possui transmitância comparável com a do ITO, o que poderia fazer dele um bom substituto, mas como a resistividade, vista na tabela 6.1.1, é alta, ainda há necessidade de melhoras antes da aplicação em células solares.

$\mathrm{Na}$ região infravermelha, vemos que as amostras possuem valores de transmitância bem próximos, o que sugere que a quantidade de portadores livres também seja praticamente a mesma. De fato, os valores de resistividade apresentados na tabela 6.1.1 sugerem que isto seja verdade, desde que a mobilidade dos portadores também seja a mesma. Podemos, todavia, confirmar a teoria de que no infravermelho a transmitância realmente é reduzida devido à absorção de radiação pelos portadores livres.

Podemos, todavia, confirmar a teoria de que quanto maior o comprimento de onda, maior é a absorção do material pelos portadores, já que claramente a transmitância diminui com o aumento do comprimento de onda.

\subsubsection{ZnO e ZnO:Al}

Abaixo encontram-se os espectros de transmitância dos filmes de $\mathrm{ZnO}$ e ZnO:Al e seus respectivos gráficos de absorção.

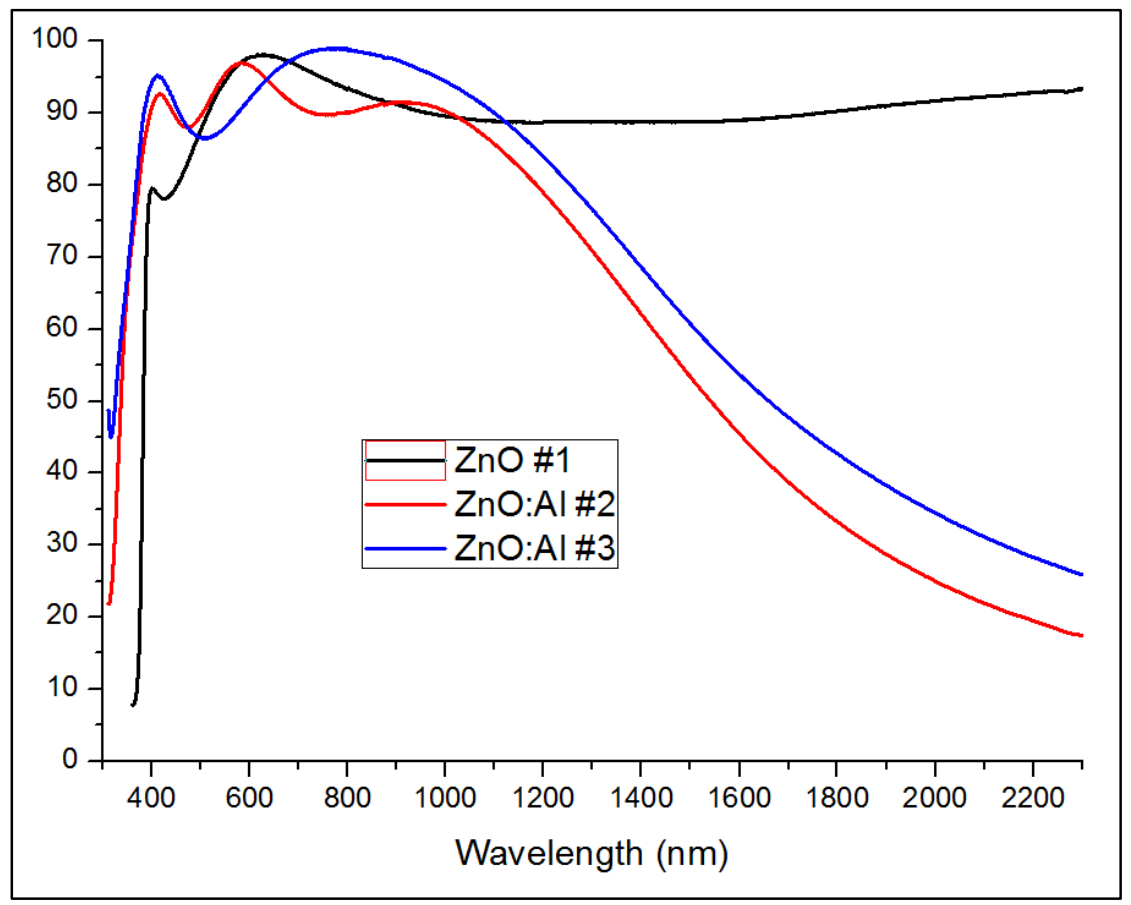

Figura 6.2.4 - Transmitâncias das amostras de ZnO e ZnO:Al 


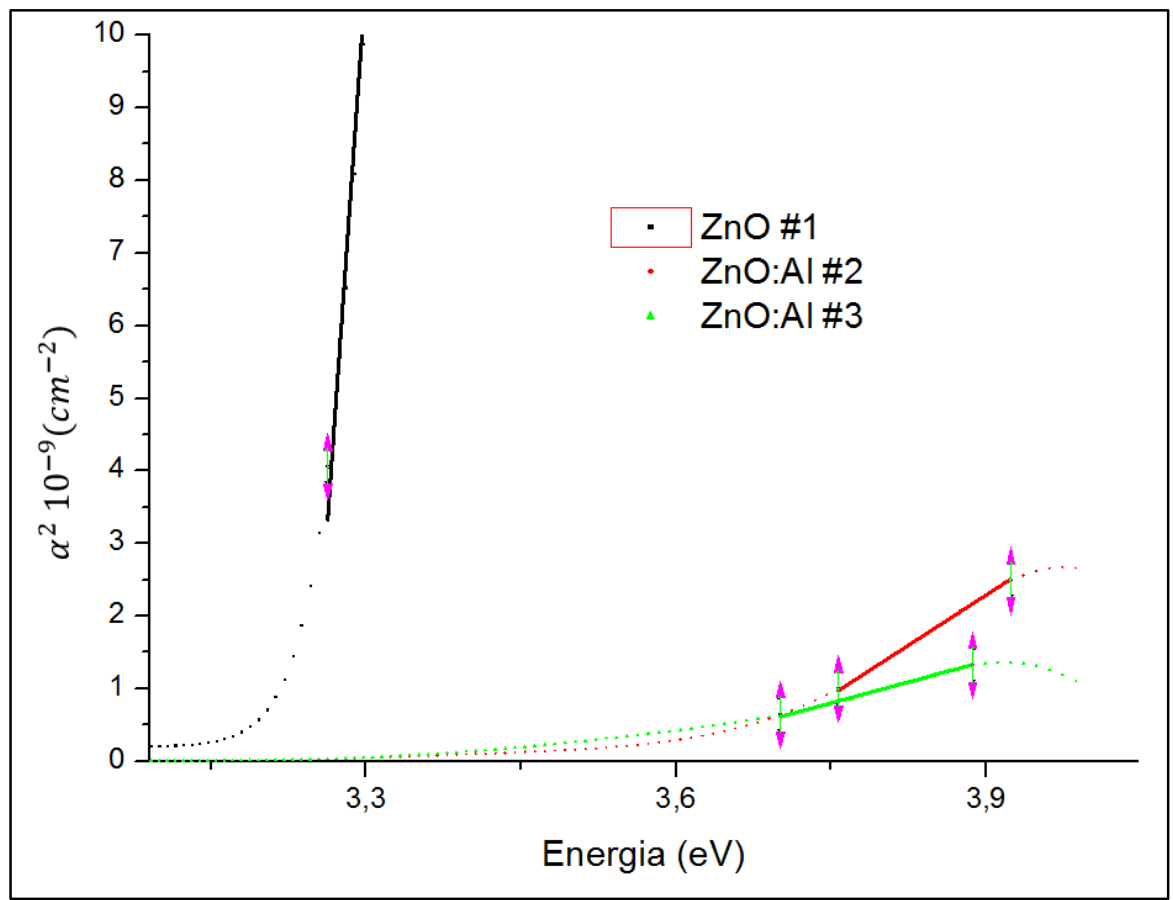

Figura 6.2.5 - Gráfico $\alpha^{2}\left(\mathrm{~cm}^{-2}\right)$ vs. hv (eV) das amostras de $\mathrm{ZnO}$ e $\mathrm{ZnO}$ :Al

Seguindo os mesmos passos da análise dos filmes de $\mathrm{SnO}_{2}$, foram calculados os valores de Eg para os filmes de $\mathrm{ZnO}$ e $\mathrm{ZnO}: \mathrm{Al}$, lembrando que o valor da banda proibida para o $\mathrm{ZnO}$ não dopado é de 3,37 eV.

\begin{tabular}{|c|c|c|}
\hline Material & $\#$ & $\mathrm{Eg} \mathrm{(eV)}$ \\
\hline $\mathrm{ZnO}$ & 1 & 3,25 \\
\hline $\mathrm{ZnO}-\mathrm{Al}$ & 2 & 3,65 \\
\hline $\mathrm{ZnO}-\mathrm{Al}$ & 3 & 3,54 \\
\hline
\end{tabular}

Tabela 6.2.3 - Valores de Eg dos filmes de ZnO e ZnO:Al

Foram obtidos altos valores de $\mathrm{Eg}$, o que é um ótimo sinal para aplicações como contato frontal de células solares, já que não irão ocorrer transições entre as bandas com fótons dentro do espectro visível. Outra observação é que o Eg do ZnO ficou próximo ao Eg teórico e quando adicionado alumínio, o valor da banda proibida cresce.

\begin{tabular}{|c|c|c|}
\hline Material & $\#$ & $\% \mathrm{~T}$ \\
\hline $\mathrm{ZnO}$ & 1 & 91,90 \\
\hline $\mathrm{ZnO}-\mathrm{Al}$ & 2 & 92,10 \\
\hline $\mathrm{ZnO}-\mathrm{Al}$ & 3 & 93,40 \\
\hline
\end{tabular}

Tabela 6.2.4 - Valores de \% T no visível dos filmes de $\mathrm{ZnO}$ e $\mathrm{ZnO}: \mathrm{Al}$ 
Foram obtidos também altos valores de transmitância no visível e com valores acima de $90 \%$, esses materiais se tornam grandes concorrentes para substituir o ITO em células solares.

Finalizando a análise do espectro, vemos claramente que existe grande diferença entre o $\mathrm{ZnO}$ dopado com $\mathrm{Al}$ e o $\mathrm{ZnO}$ puro. Isso é exatamente o que é esperado com a dopagem de semicondutores que tenham suas condutividades severamente aumentadas com a adição de pequenas concentrações de átomos diferentes. As transmitâncias dos filmes dopados na região infravermelha possuem valores muito menores que as do filme de $\mathrm{ZnO}$ puro, o que é perfeitamente explicado pela teoria da absorção por elétrons livres e corroborado pelas medidas de resistividade da tabela 6.1.1.

Portanto, filmes de $\mathrm{ZnO}$ puro possuem boa transmitância, porém baixa condutividade. Isso é contornado pela dopagem de alumínio, o que mantém a alta transmitância e reduz em 6 ordens de grandeza a resistividade do filme.

\subsection{3 $\quad \ln _{2} \mathrm{O}_{3}$}

Abaixo encontram-se os espectros de transmitância dos filmes de $\ln _{2} \mathrm{O}_{3} \mathrm{e}$ seus respectivos gráficos de absorção.

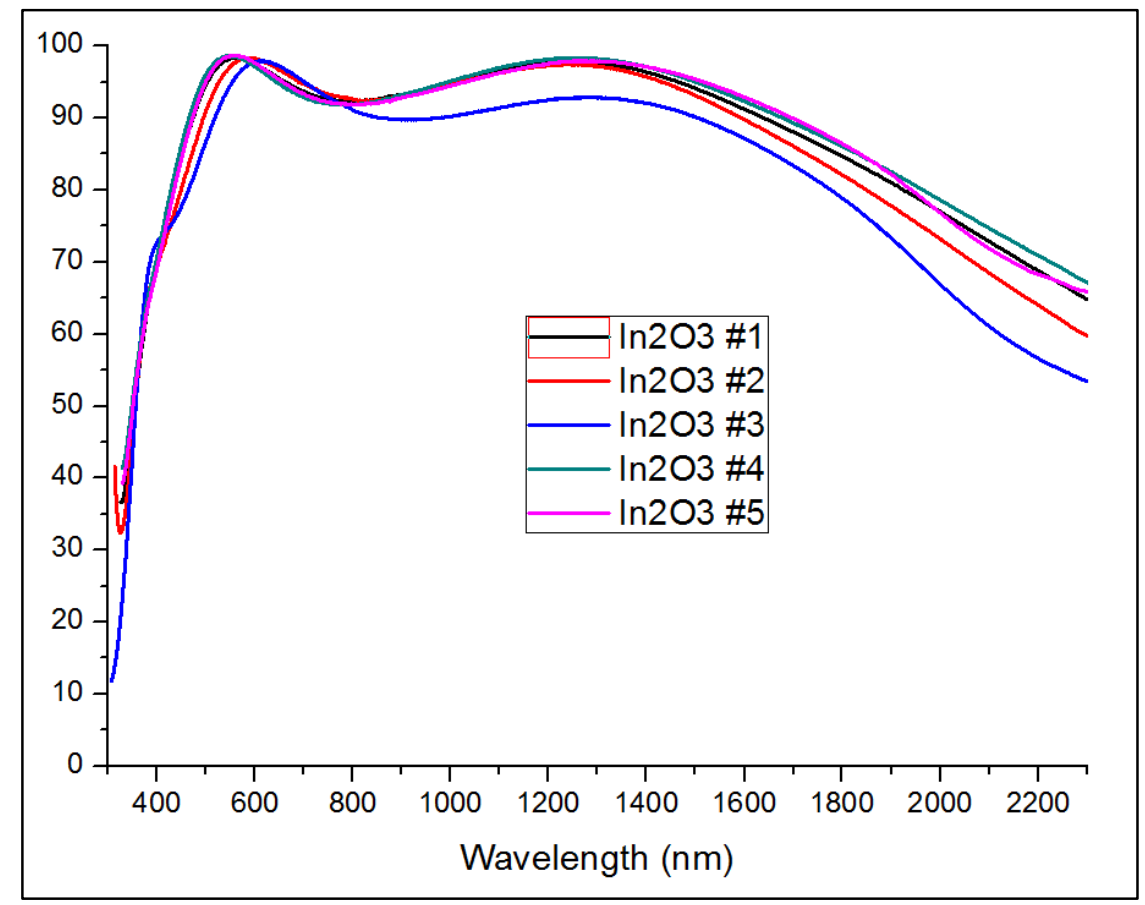

Figura 6.2.6 - Transmitâncias das amostras de $\mathrm{In}_{2} \mathrm{O}_{3}$ 


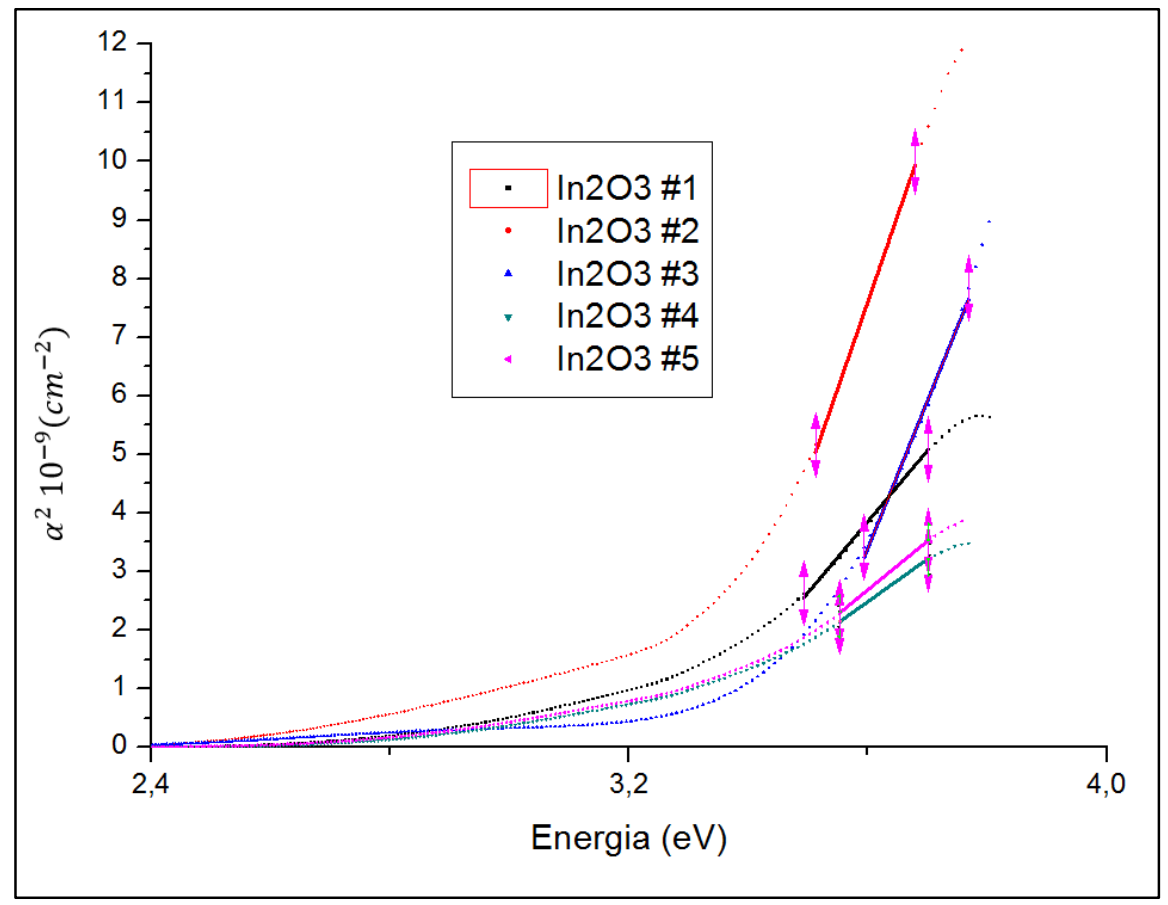

Figura 6.2.7 - Gráfico $\alpha^{2}\left(\mathrm{~cm}^{-2}\right)$ vs. hv (eV) das amostras de $\mathrm{In}_{2} \mathrm{O}_{3}$

Abaixo encontram-se os valores calculados de Eg para os filmes de $\ln _{2} \mathrm{O}_{3}$, lembrando que o valor da banda proibida para $0 \ln _{2} \mathrm{O}_{3}$ não dopado ainda é discutido por pesquisadores. As propostas variam entre 2,9 ou 3,7 eV para o gap direto e 2,6 eV para o indireto.

\begin{tabular}{|c|c|c|}
\hline Material & $\#$ & $\mathrm{Eg}(\mathrm{eV})$ \\
\hline $\mathrm{In}_{2} \mathrm{O}_{3}$ & 1 & 3,29 \\
\hline $\mathrm{In}_{2} \mathrm{O}_{3}$ & 2 & 3,34 \\
\hline $\mathrm{In}_{2} \mathrm{O}_{3}$ & 3 & 3,47 \\
\hline $\mathrm{In}_{2} \mathrm{O}_{3}$ & 4 & 3,25 \\
\hline $\mathrm{In}_{2} \mathrm{O}_{3}$ & 5 & 3,27 \\
\hline
\end{tabular}

Tabela 6.2.5 - Valores de Eg dos filmes de $\mathrm{In}_{2} \mathrm{O}_{3}$

Valores de Eg em torno de 3,3eV são bem interessantes para garantir a transparência no visível. Foi observado também que os filmes apresentam predominantemente transições diretas entre a banda de valência e a banda de condução.

Na tabela 6.2.6 estão exibidos os valores da transmitância no visível dos filmes de óxido de índio. Todos os valores estão acima de $90 \%$, o que são ótimos resultados para aplicações em contatos frontais de células solares. 


\begin{tabular}{|c|c|c|}
\hline Material & $\#$ & $\% \mathrm{~T}$ \\
\hline $\mathrm{In}_{2} \mathrm{O}_{3}$ & 1 & 92,30 \\
\hline $\ln _{2} \mathrm{O}_{3}$ & 2 & 91,60 \\
\hline $\ln _{2} \mathrm{O}_{3}$ & 3 & 90,50 \\
\hline $\ln _{2} \mathrm{O}_{3}$ & 4 & 92,50 \\
\hline $\ln _{2} \mathrm{O}_{3}$ & 5 & 92,20 \\
\hline
\end{tabular}

Tabela 6.2.6 - Valores de \% $\mathrm{T}$ no visível dos filmes de $\mathrm{In}_{2} \mathrm{O}_{3}$

Na região infravermelha do espectro de transmitância, o único dado que se pode inferir é que a amostra 3 é a menos resistiva, o que de fato ocorre quando comparada aos valores da tabela 6.1.1. Nesse caso, vemos que a transmitância desse filme é um pouco menor e sua espessura maior, logo as diferenças observadas são causadas pelas variações de espessura e não por uma diferença nas propriedades do material.

\subsection{4 $\mathrm{Zn}_{2} \mathrm{SnO}_{4}$}

Abaixo encontram-se os espectros de transmitância dos filmes de $\mathrm{Zn}_{2} \mathrm{SnO}_{4}$ e seus respectivos gráficos de absorção.

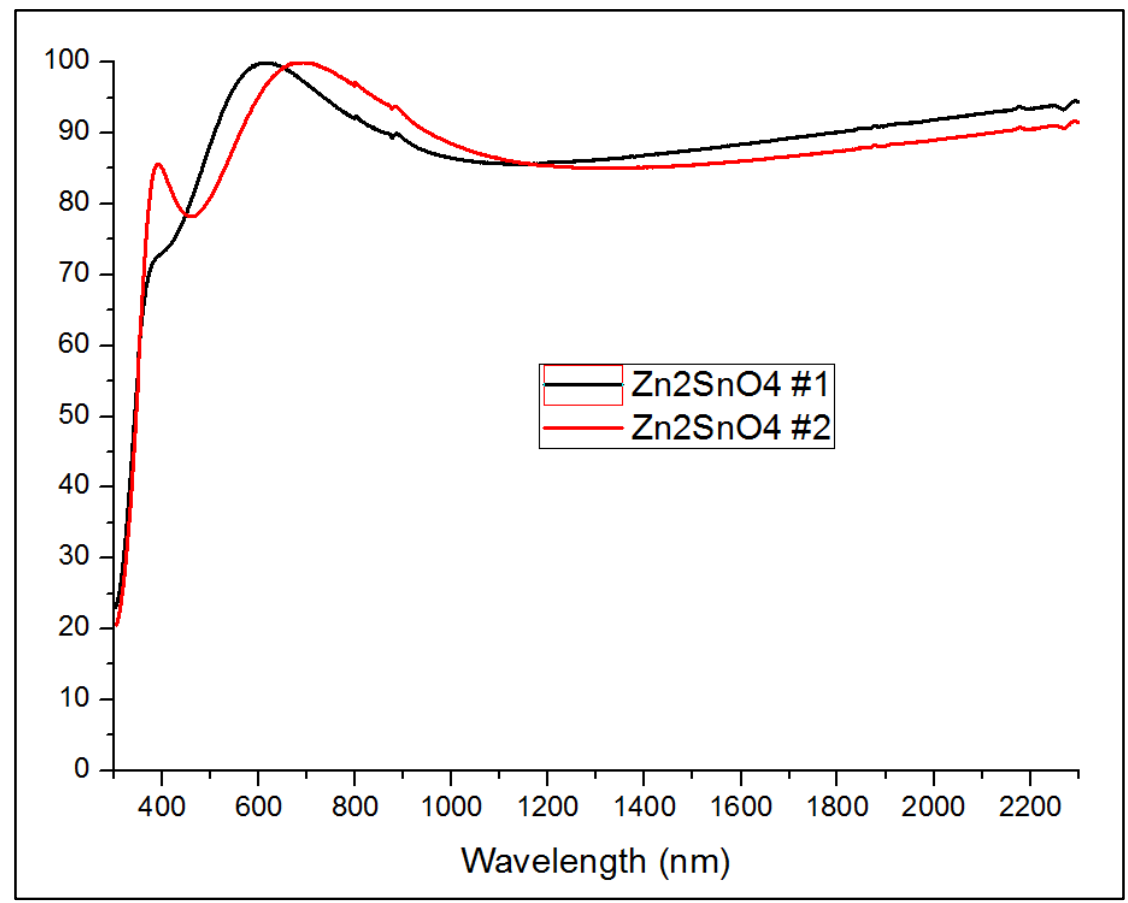

Figura 6.2.8 - Transmitâncias das amostras de $\mathrm{Zn}_{2} \mathrm{SnO}_{4}$ 


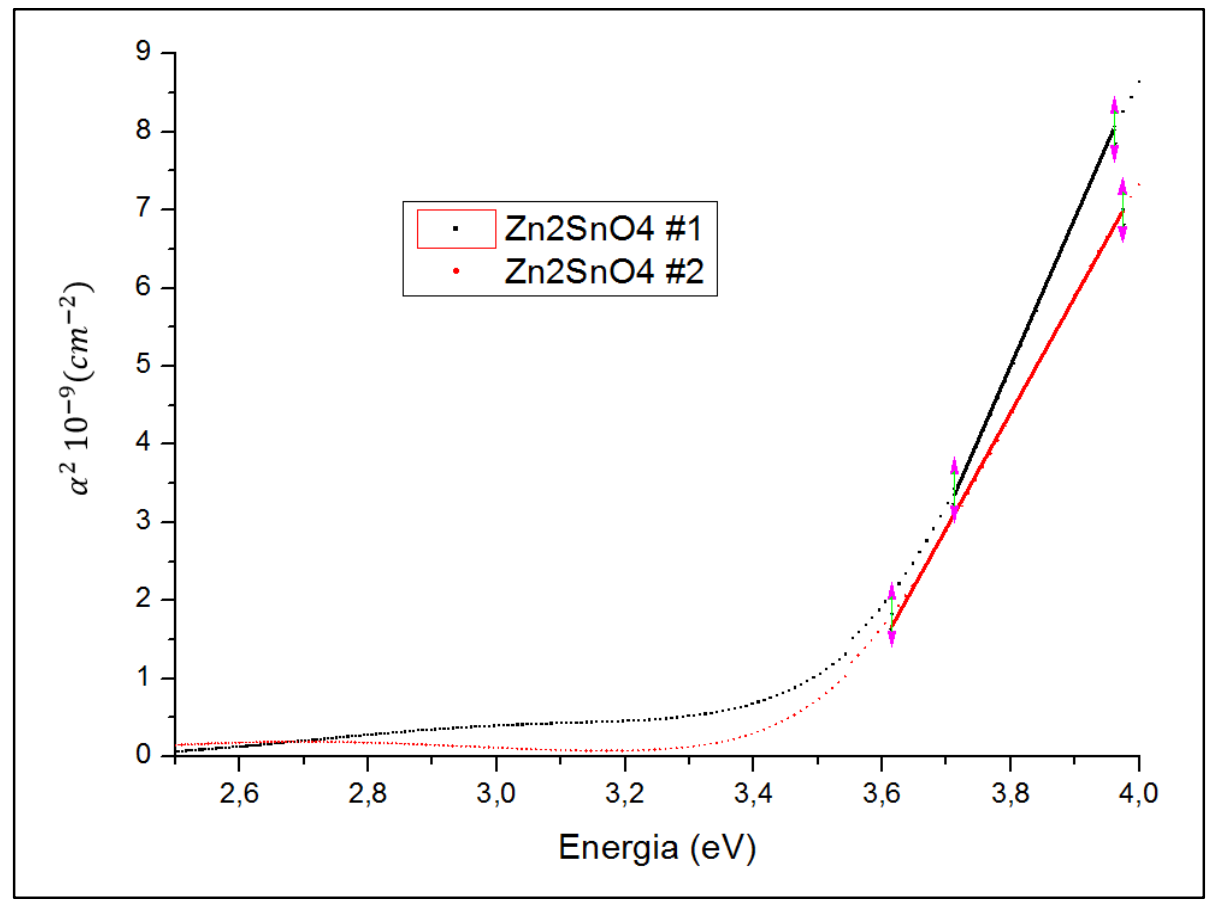

Figura 6.2.9 - Gráfico $\alpha^{2}\left(\mathrm{~cm}^{-2}\right)$ vs. hv (eV) das amostras de $\mathrm{Zn}_{2} \mathrm{SnO}_{4}$

\begin{tabular}{|c|c|c|}
\hline Material & $\#$ & $\mathrm{Eg} \mathrm{(eV)}$ \\
\hline $\mathrm{Zn}_{2} \mathrm{SnO}_{4}$ & 1 & 3,54 \\
\hline $\mathrm{Zn}_{2} \mathrm{SnO}_{4}$ & 2 & 3,50 \\
\hline
\end{tabular}

Tabela 6.2.7 - Valores de Eg dos filmes de $\mathrm{Zn}_{2} \mathrm{SnO}_{4}$

Espera-se que filmes de $\mathrm{Zn}_{2} \mathrm{SnO}_{4}$ possuam valores de Eg entre 3,6 e 3,7, logo os valores medidos em torno de 3,5 eV estão bem próximos ao valor teórico. Mais uma vez, confirma-se que esse material possui absorção na região ultravioleta, o que pode significar boa transmitância no visível.

\begin{tabular}{|c|c|c|}
\hline Material & $\#$ & \%T \\
\hline $\mathrm{Zn}_{2} \mathrm{SnO}_{4}$ & 1 & 92,1 \\
\hline $\mathrm{Zn}_{2} \mathrm{SnO}_{4}$ & 2 & 91,4 \\
\hline
\end{tabular}

Tabela 6.2.8 - Valores de \% T no visível dos filmes de $\mathrm{Zn}_{2} \mathrm{SnO}_{4}$

Com transmitâncias acima de $90 \%$, filmes de $\mathrm{Zn}_{2} \mathrm{SnO}_{4}$ são oticamente favoráveis para a aplicação em células solares. Eletricamente, no entanto, elas apresentaram alta resistividade (tabela 6.1.1). O espectro na região do infravermelho confirmou a baixa quantidade de portadores livres, pois não houve absorção. 


\subsection{5 $\mathrm{Cd}_{2} \mathrm{SnO}_{4}$}

Abaixo encontram-se os espectros de transmitância dos filmes de $\mathrm{Cd}_{2} \mathrm{SnO}_{4}$ e seus respectivos gráficos de absorção.

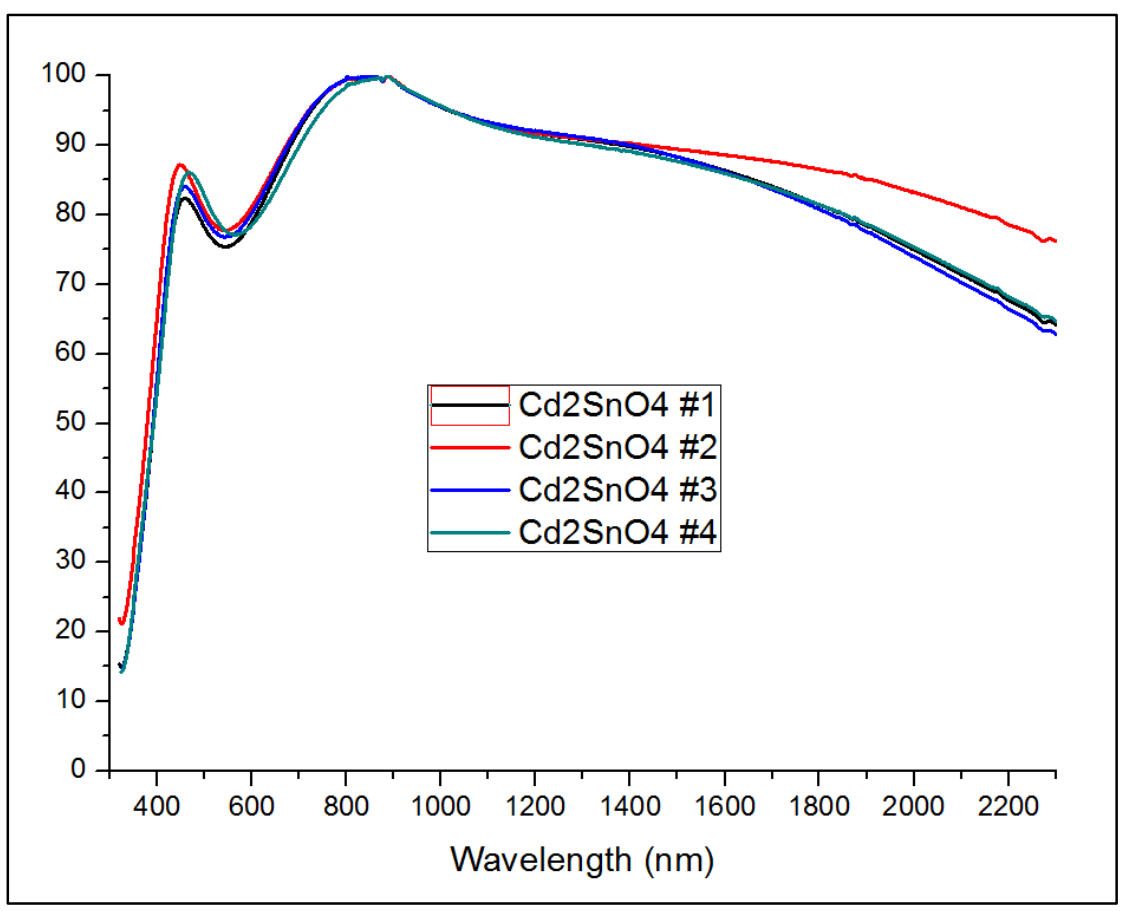

Figura 6.2.10 - Transmitâncias das amostras de $\mathrm{Cd}_{2} \mathrm{SnO}_{4}$

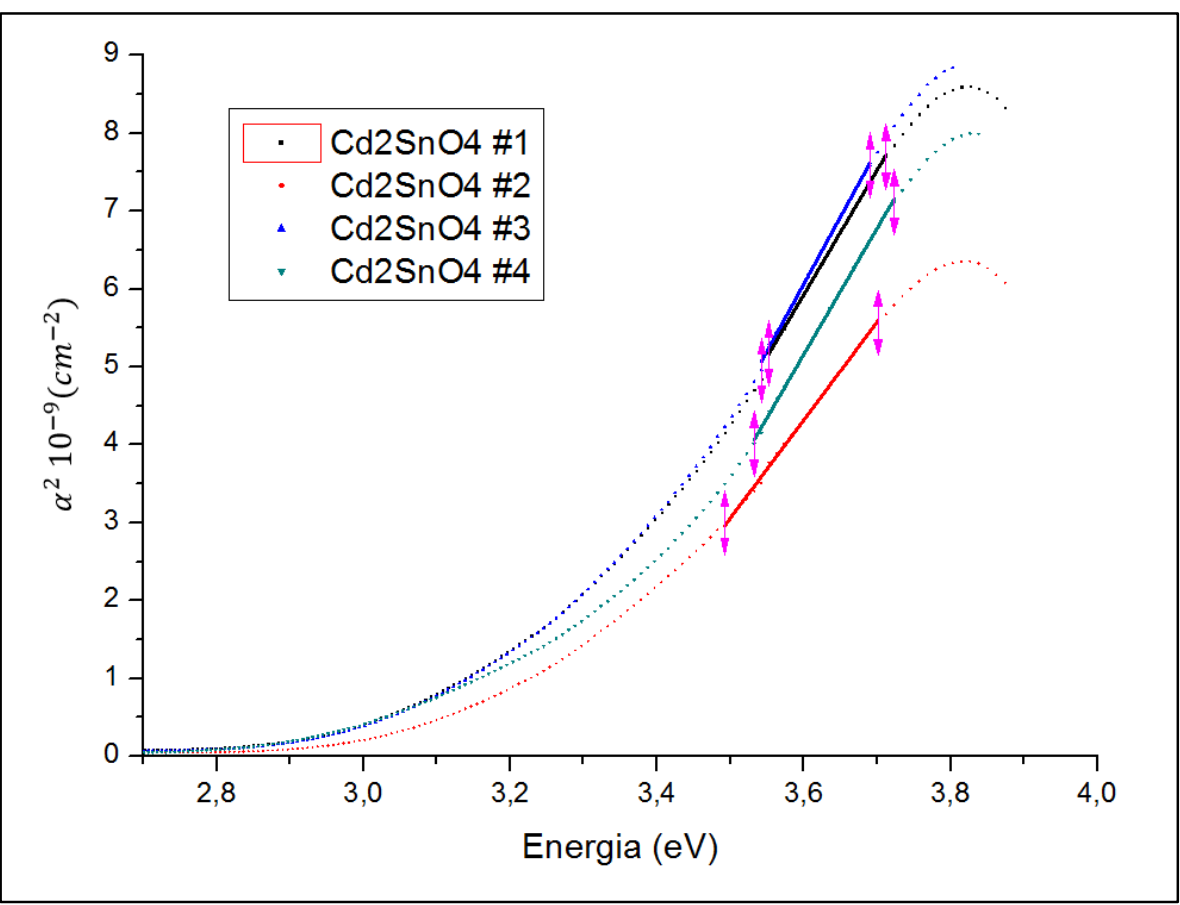

Figura 6.2.11 - Gráfico $\alpha^{2}\left(\mathrm{~cm}^{-2}\right)$ vs. hv (eV) das amostras de $\mathrm{Cd}_{2} \mathrm{SnO}_{4}$ 
Como feito em todos os filmes anteriores, o gráfico de $\alpha^{2}$ foi aproximado por uma reta na região de absorção fundamental, permitindo o cálculo do Eg. Os valores calculados se encontram na tabela 6.2.9.

\begin{tabular}{|c|c|c|}
\hline Material & $\#$ & $\mathrm{Eg} \mathrm{(eV})$ \\
\hline $\mathrm{Cd}_{2} \mathrm{SnO}_{4}$ & 1 & 3,23 \\
\hline $\mathrm{Cd}_{2} \mathrm{SnO}_{4}$ & 2 & 3,26 \\
\hline $\mathrm{Cd}_{2} \mathrm{SnO}_{4}$ & 3 & 3,25 \\
\hline $\mathrm{Cd}_{2} \mathrm{SnO}_{4}$ & 4 & 3,28 \\
\hline
\end{tabular}

Tabela 6.2.9 - Valores de Eg dos filmes de $\mathrm{Cd}_{2} \mathrm{SnO}_{4}$

Foram observadas transições diretas nas análises dos gráficos e valores entre 3,2 e 3,3 eV, o que está dentro da faixa de 3,0-3,3 eV teórica para os filmes. Isso fez dos filmes de $\mathrm{Cd}_{2} \mathrm{SnO}_{4}$ serem os com o segundo menor valor para a largura da banda proibida, mas mesmo assim, capazes de desempenhar eficientemente a função de contato frontal.

\begin{tabular}{|c|c|c|}
\hline Material & $\#$ & $\% \mathrm{~T}$ \\
\hline $\mathrm{Cd}_{2} \mathrm{SnO}_{4}$ & 1 & 83,8 \\
\hline $\mathrm{Cd}_{2} \mathrm{SnO}_{4}$ & 2 & 86,2 \\
\hline $\mathrm{Cd}_{2} \mathrm{SnO}_{4}$ & 3 & 84,8 \\
\hline $\mathrm{Cd}_{2} \mathrm{SnO}_{4}$ & 4 & 83,8 \\
\hline
\end{tabular}

Tabela 6.2.10 - Valores de \% $\mathrm{T}$ no visível dos filmes de $\mathrm{Cd}_{2} \mathrm{SnO}_{4}$

Com transmitâncias no visível em torno de $85 \%$, esse material também comprovou suas propriedades óticas como todos os TCO estudados.

Pela análise da região infravermelha do espectro, vemos que a amostra 2 é a que menos absorve radiação, o que está de acordo com o fato de ela possuir a maior resistividade, conforme mostra a tabela 6.1.1. Vale observar que os filmes de CTO possuem ótimos valores de resistividade apesar de que os valores em torno de $1,0 \times 10^{-3} \Omega$.cm ainda estarem longe dos valores obtidos por outras pesquisas, que estão próximos a $1.28 \times 10^{-4} \Omega$.cm. 


\subsection{Considerações finais}

Os valores das propriedades dos filmes foram unificados na tabela 6.3.1 e alguns espectros de transmitância foram escolhidos para comparar os filmes e suas propriedades.

Tabela 6.3.1 - Amostras analisadas e seus dados de medidos ou calculados

\begin{tabular}{|c|c|c|c|c|c|}
\hline Material & $\#$ & Espessura $(\mathrm{A})$ & Resistividade $\left(\Omega^{*} \mathrm{~cm}\right)$ & $\mathrm{Eg}(\mathrm{eV})$ & $\% \mathrm{~T}$ \\
\hline $\mathrm{SnO}_{2}$ & 1 & 1551 & ${ }^{* * *}$ & 2,204 & 85,30 \\
\hline $\mathrm{SnO}_{2}$ & 2 & 1527 & ${ }^{* * *}$ & 2,222 & 86,70 \\
\hline $\mathrm{SnO}_{2}$ & 3 & 1522 & $2,90 \mathrm{E}-03$ & 2,147 & 84,50 \\
\hline $\mathrm{SnO}_{2}$ & 4 & 1563 & $2,80 \mathrm{E}-03$ & 2,180 & 84,60 \\
\hline $\mathrm{SnO}_{2}$ & 5 & 1557 & $3,10 \mathrm{E}-03$ & 2,166 & 86,50 \\
\hline $\mathrm{ZnO}$ & 1 & 1566 & $>1 \mathrm{M}$ & 3,25 & 91,90 \\
\hline $\mathrm{ZnO}-\mathrm{Al}$ & 2 & 2948 & $1,00 \mathrm{E}-03$ & 3,65 & 92,10 \\
\hline $\mathrm{ZnO}-\mathrm{Al}$ & 3 & 2161 & $8,60 \mathrm{E}-04$ & 3,54 & 93,40 \\
\hline $\mathrm{In}_{2} \mathrm{O}_{3}$ & 1 & 1336 & $3,40 \mathrm{E}-04$ & 3,29 & 92,30 \\
\hline $\mathrm{In}_{2} \mathrm{O}_{3}$ & 2 & 1015 & $2,40 \mathrm{E}-04$ & 3,34 & 91,60 \\
\hline $\mathrm{In}_{2} \mathrm{O}_{3}$ & 3 & 1664 & $4,00 \mathrm{E}-04$ & 3,47 & 90,50 \\
\hline $\mathrm{In}_{2} \mathrm{O}_{3}$ & 4 & 1492 & ${ }^{* * *}$ & 3,25 & 92,50 \\
\hline $\mathrm{In}_{2} \mathrm{O}_{3}$ & 5 & 1505 & ${ }^{* * *}$ & 3,27 & 92,20 \\
\hline $\mathrm{Zn}_{2} \mathrm{SnO}_{4}$ & 1 & 1495 & $9,10 \mathrm{E}-01$ & 3,54 & 92,10 \\
\hline $\mathrm{Zn}_{2} \mathrm{SnO}_{4}$ & 2 & 1770 & $2,10 \mathrm{E}+00$ & 3,50 & 91,40 \\
\hline $\mathrm{Cd}_{2} \mathrm{SnO}_{4}$ & 1 & 2050 & $9,70 \mathrm{E}-04$ & 3,23 & 83,80 \\
\hline $\mathrm{Cd}_{2} \mathrm{SnO}_{4}$ & 2 & 1949 & $1,30 \mathrm{E}-03$ & 3,26 & 86,20 \\
\hline $\mathrm{Cd}_{2} \mathrm{SnO}_{4}$ & 3 & 2037 & ${ }^{* * *}$ & 3,25 & 84,80 \\
\hline $\mathrm{Cd}_{2} \mathrm{SnO}_{4}$ & 4 & 2181 & $9,30 \mathrm{E}-04$ & 3,28 & 83,80 \\
\hline
\end{tabular}

Os melhores filmes de TCO para servirem de contatos frontais de células solares segundo as propriedades acima são os filmes de $\mathrm{ZnO}$ :Al e de $\ln _{2} \mathrm{O}_{3}$, seguidos pelos filmes de $\mathrm{Cd}_{2} \mathrm{SnO}_{4}$ que apresentam boa resistividade, mas menor \%T. Filmes de $\mathrm{SnO}_{2}$ apresentaram resistividade relativamente alta e transmitância mais baixa que os outros filmes, ficando em terceiro lugar. Já os filmes de $\mathrm{ZnO}$ e $\mathrm{Zn}_{2} \mathrm{SnO}_{4}$ possuem ótima transmitância no visível, mas possuem valores muito altos de resistividade o que impossibilita sua utilização condutiva. 
É também possível ver na tabela 6.3.1 que a condutividade e o valor da largura da banda proibida $(\mathrm{Eg})$ não se relacionam diretamente. Na verdade, o valor da banda está diretamente relacionado ao número de portadores do material, o que afeta a resistividade. Esta, porém, depende também da mobilidade dos portadores, a qual é afetada por defeitos da rede cristalina do material.

Foram escolhidos os espectros de transmitância dos filmes de $\mathrm{ZnO} \# 1$, ZnO:Al \#2, $\mathrm{Zn}_{2} \mathrm{SnO}_{4} \# 2$ e $\mathrm{Cd}_{2} \mathrm{SnO}_{4} \# 1$ para uma análise final das informações possíveis de se obter através de espectros de transmitância.

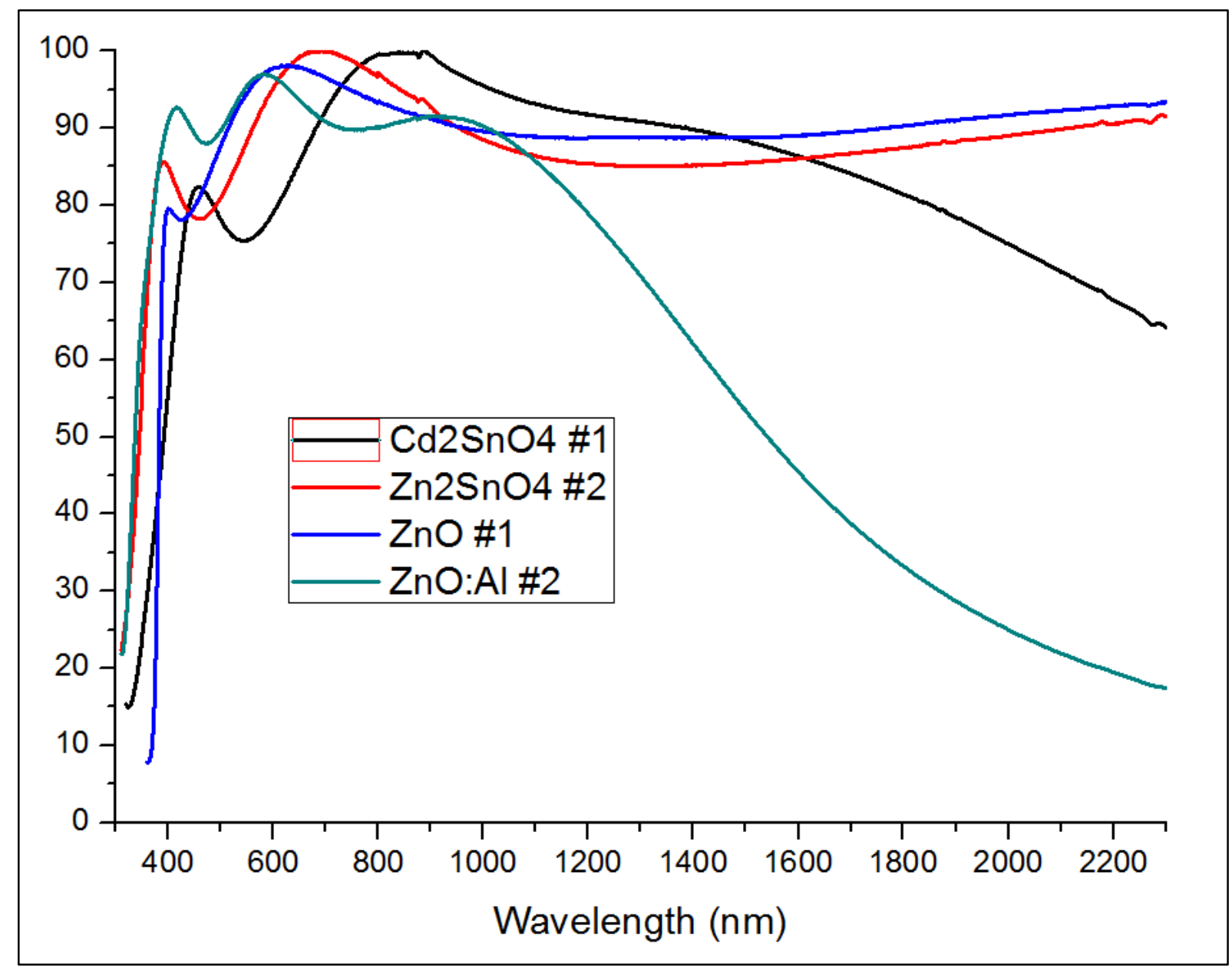

Figura 6.3.1 - Transmitâncias escolhidas

A análise pretendida nesse gráfico é da região infravermelha entre $1000 \mathrm{e}$ $2300 \mathrm{~nm}$. Como discutido anteriormente, nessa região podemos ter informações sobre a quantidade de portadores de carga no semicondutor.

Vemos que a absorção no infravermelho dos filmes escolhidos se dá da seguinte forma: as linhas dos filmes de $\mathrm{ZnO} \# 1$ e $\mathrm{Zn}_{2} \mathrm{SnO}_{4} \# 2$ estão muito próximas entre si e bem próximas ao topo do espectro, logo devem ter poucos portadores. Em 
seguida é vista a linha do $\mathrm{Cd}_{2} \mathrm{SnO}_{4} \# 1$ e por último a do $\mathrm{ZnO}: \mathrm{Al} \# 2$, bem separadas, indicando que ambas teriam mais portadores livres do que os outros filmes, sendo o ZnO:Al \#2 o que possui maior número de portadores. Na tabela 6.3.2 estão os valores de suas resistividades:

\begin{tabular}{|c|c|c|}
\hline Material & $\#$ & Resistividade $\left(\Omega^{*} \mathrm{~cm}\right)$ \\
\hline $\mathrm{ZnO}$ & 1 & $>1 \mathrm{M}$ \\
\hline $\mathrm{Zn}_{2} \mathrm{SnO}_{4}$ & 2 & $2,10 \mathrm{E}+00$ \\
\hline $\mathrm{ZnO}-\mathrm{Al}$ & 2 & $1,00 \mathrm{E}-03$ \\
\hline $\mathrm{Cd}_{2} \mathrm{SnO}_{4}$ & 1 & $9,70 \mathrm{E}-04$ \\
\hline
\end{tabular}

Tabela 6.3.2 - Resistividade das amostras escolhidas

Vemos de fato que $\mathrm{ZnO} \# 1$ e $\mathrm{Zn}_{2} \mathrm{SnO}_{4}$ \# 2 são as amostras mais resistivas, resultado do baixo número de portadores livres. No entanto, a amostra mais condutora

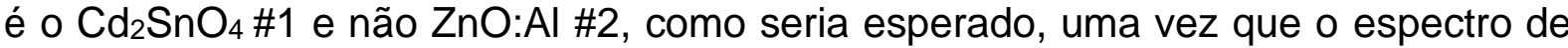
transmitância indica que este último possui um número maior de portadores livres. É possível que a mobilidade dos portadores no ZnO:Al \#2 seja baixa e isto tenha limitado a resistividade. Além disso, a resistividade de $\mathrm{ZnO} \# 1$ é muitas ordens de grandeza maior que a do $\mathrm{Zn}_{2} \mathrm{SnO}_{4} \# 2$. Isso nos mostra que a análise do infravermelho é apenas interessante qualitativamente quando aplicada à materiais semelhantes, porque quando se quer comparar materiais diferentes, o espectro de transmitância na região do infravermelho é uma escolha ruim de método de caracterização. 


\section{Conclusão}

O estudo das propriedades óticas e elétricas dos materiais semicondutores TCO permitiu uma comparação entre as transmitâncias e as resistividades dos mesmos de forma a identificar candidatos para aplicação em células solares.

Foi possível identificar em todos os filmes as propriedades de interesse: largura da banda proibida (Eg), valores de transmitância no visível (\%T) e a influência da quantidade de portadores livres na resistividade do material.

Já a investigação da influência dos portadores na resistividade do material através da análise da região infravermelha dos espectros de transmitância se mostrou um bom método qualitativo apenas quando aplicado em materiais com composição semelhante. Quando materiais diferentes são comparados, a análise dessa região se torna inconclusiva, logo não deve ser utilizada para esse fim.

Finalmente, dentre os TCO estudados, os filmes finos com as melhores propriedades para aplicação em contatos frontais de células solares são o ZnO:Al e de $\ln _{2} \mathrm{O}_{3}$. Levando-se em consideração o elevado custo do $\ln _{2} \mathrm{O}_{3}$, este estudo indica que o melhor material para ser utilizado nas células solares é o ZnO:Al por apresentar alta transmitância no visível (acima de 92\%) e baixa resistividade (abaixo de 10-3 $\Omega . c m)$. 


\section{Referências}

1. Eisberg, Robert; Resnick Robert. Física Quântica Átomos, Moléculas, Sólidos Núcleos e Partículas; Rio de Janeiro: Campus, 1986

2. Chen, Z, Li, W, Li, R, Zhang, Y, Xu, G \& Cheng, H (2013). Fabrication of Highly Transparent and Conductive Indium-Tin Oxide Thin Films with a High Figure of Merit via Solution Processing. Langmuir, pp. 13836-13842

3. European Comission, Indium. Disponível em: <https://setis.ec.europa.eu/mis/material/indium>. Acesso em: 12 nov. 2015.

4. London Metal Exchange, Tin. Disponível em: <https://www.Ime.com/metals/non-ferrous/tin/>. Acesso em: 12 nov. 2015.

5. Callister, W. D. Ciência de Engenharia de Materiais: Uma Introdução, $7^{\mathrm{a}}$ ed.; Rio de Janeiro: LTC, 2008

6. Chalabi, H., \& Brongersma, M. (2013). Plasmonics: Harvest season for hot electrons. Nature Nanotech Nature Nanotechnology, 229-230

7. Fraser, D. (1986). The physics of semiconductor devices (4th ed.). Oxford University Press, New York

8. Kasap, S., Capper, P. (2006). Springer handbook of electronic and photonic materials. Springer. pp. 54,327. ISBN 0-387-26059-5.

9. Kasap, S. (2006). Principles of electronic materials and devices (3rd ed.). Boston: McGraw-Hill.

10. Conibeer, G. (2007). Third-generation photovoltaics. Materials Today, 42-50.

11. Badeker, K. (1907) Ann Phys. (Leipzig) 22 p. 749.

12. Bright, C. (2008). Review of Transparent Conductive Oxides (TCO)

13. Tuna, O., Selamet, Y., Aygun, G., \& Ozyuzer, L. (2010). High quality ITO thin films grown by dc and RF sputtering without oxygen. Journal of Physics D: Applied Physics J. Phys. D: Appl. Phys., 055402-055402.

14. Cachet, H. (2005) Films and powders of fluorine-doped tin dioxide. In Fluorinated Materials for Energy Conversion; Tsuyoshi, N., Henri, G., Eds.; Elsevier Science: Amsterdam, The Netherlands; pp. 513-534. 
15. J.C. Manifacier, M. De Murcia, J.P. Fillard, E. Vicario. (1977). Optical and electrical properties of $\mathrm{SnO}_{2}$ thin films in relation to their stoichiometric deviation and their crystalline structure. Thin Solid Films.41: 127-144.

16. Robertson, J., \& Falabretti, B. (2010). Electronic Structure of Transparent Conducting Oxides. Handbook of Transparent Conductors, 27-50.

17. Milão, T.; Oliveira, J.; Araújo, V.; Bernardi, M. (2011). Zno.97M0.03O (M= $\mathrm{Co}, \mathrm{Fe}$, and V) pigments: thermal, structural, and optical characterization. Journal of thermal analysis and calorimetry, Vol. 103, p. 873-877.

18. Seeber, W., Abou-Helal, M., Barth, S., Beil, T., Hoche, T., Demian, S. (1999). Transparent semiconducting ZnO:Al thin films prepared by spray pyrolysis. Material Science in Semiconductor Processing, 2: 45-55

19. Gondoni, P., Ghidelli, M., Di Fonzo, F., Russo, V., Bruno, P., MartíRujas, J., Bottani, C., Li Bassi, A., Casari, C. (2012). Highly Performing Al:ZnO Thin Films Grown by Pulsed Laser Deposition at Room Temperature. 520, 4707

20. Beena, D., Lethy, K., Vinodkumar, R., Detty, A., Pillai, V., \& Ganesan, V. (2011). Photoluminescence in laser ablated nanostructured indium oxide thin films. Journal of Alloys and Compounds, 215-223

21. D. Liu, W. W. Lei, B. Zou, S. D. Yu, J. Hao, K. Wang, B. B. Liu, Q. L. Cui, G. T. Zou J. Appl. Phys 104, 083506 (2008).

22. R. L. Weiher, R. P. Ley, J. Appl. Phys 37, 299 (1966).

23. Enoki, H., Nakayama, T., \& Echigoya, J. (1992). The Electrical and Optical Properties of the $\mathrm{ZnO}^{-\mathrm{SnO}_{2}}$ Thin Films Prepared by RF Magnetron Sputtering. Physica Status Solidi (a) Phys. Stat. Sol. (a), 181-191.

24. Jin, M., Shulai, H., Honglei, M., Lingyun, G. (2003) Preparation and characterization of transparent conducting $\mathrm{Zn}-\mathrm{Sn}-\mathrm{O}$ films deposited on organic substrates at low temperature. SCIENCE CHINA Physics,Mechanics \& Astronomy, 46(6): 619-624 .

25. Alpuche-Aviles, M., \& Wu, Y. (2009). Photoelectrochemical Study of the Band Structure of $\mathrm{Zn}_{2} \mathrm{SnO}_{4}$ Prepared by the Hydrothermal Method. J. Am. Chem. Soc. Journal of the American Chemical Society, 3216-3224.

26. Wu, X., Mulligan, W.P., Coutts, T.J., (1996) Thin Solid Films 286274 276. 
27. Jeyadheepan, K., Thamilselvan, M., Kim, K., Yi, J., \& Sanjeeviraja, C. (2015). Optoelectronic properties of R-F magnetron sputtered Cadmium Tin Oxide $\left(\mathrm{Cd}_{2} \mathrm{SnO}_{4}\right)$ thin films for $\mathrm{CdS} / \mathrm{CdTe}$ thin film solar cell applications. Journal of Alloys and Compounds, 185-191.

28. UC Davis, Spectrophotometry. Disponível em: $<$ http://chemwiki.ucdavis.edu/Physical_Chemistry/Kinetics/Reaction_Rates/Experime ntal_Determination_of_Kinetcs/Spectrophotometry>. Acesso em: 15 nov. 2015.

29. Cruz, L., Legnani, C., Matoso, I., Ferreira, C., \& Moutinho, H. (2004). Influence of pressure and annealing on the microstructural and electro-optical properties of RF magnetron sputtered ITO thin films. Materials Research Bulletin, 993-1003.

30. Fahrenbruch, A. L. e Bube, R.H. Fundamental of solar cells. Academic press, New York. 1983.

31. Kasap, S. (2001). Optoelectronics and photonics: Principles and practices. Upper Saddle River, NJ: Prentice Hall.

32. Manifacier, J., Gasiot, J., \& Fillard, J. (1976). A simple method for the determination of the optical constants $n, k$ and the thickness of a weakly absorbing thin film. J. Phys. E: Sci. Instrum. Journal of Physics E: Scientific Instruments, 1002-1004.

33. University of Reading, Infrared material absorption theory. Disponível em: <https://www.reading.ac.uk/infrared/library/absorptiontheory/ir-absorptiontheoryintroduction.aspx>. Acesso em 16 nov. 2015.

34. Amirtharaj, P., \& Seiler, D. (1995). Optical properties of semiconductors. Gaithersburg, Maryland: National Institute of Standards and Technology.

35. Parshin, D., Shabaev, A., (1987) Theory of linear IR absorption by semiconductors with degenerate bands. Zh. Eksp. Teor. Fiz. 92, 1471-1484

36. Lake Shore 7500/9500 Series Hall System User's Manual 